\title{
Bedmap2: improved ice bed, surface and thickness datasets for Antarctica
}

P. Fretwell ${ }^{1, *}$, H. D. Pritchard ${ }^{1, *}$, D. G. Vaughan ${ }^{1}$, J. L. Bamber ${ }^{2}$, N. E. Barrand ${ }^{1}$, R. Bell ${ }^{3}$, C. Bianchi ${ }^{4}$, R. G. Bingham ${ }^{5}$, D. D. Blankenship ${ }^{6}$, G. Casassa ${ }^{7}$, G. Catania ${ }^{6}$, D. Callens ${ }^{8}$, H. Conway ${ }^{9}$, A. J. Cook ${ }^{10}$, H. F. J. Corr ${ }^{1}$, D. Damaske ${ }^{11}$, V. Damm ${ }^{11}$, F. Ferraccioli ${ }^{1}$, R. Forsberg ${ }^{12}$, S. Fujita ${ }^{13}$, Y. Gim ${ }^{14}$, P. Gogineni ${ }^{15}$, J. A. Griggs ${ }^{2}$, R. C. A. Hindmarsh ${ }^{1}$, P. Holmlund ${ }^{16}$, J. W. Holt ${ }^{6}$, R. W. Jacobel ${ }^{17}$, A. Jenkins ${ }^{1}$, W. Jokat ${ }^{18}$, T. Jordan ${ }^{1}$, E. C. King ${ }^{1}$, J. Kohler ${ }^{19}$, W. Krabill ${ }^{20}$, M. Riger-Kusk ${ }^{21}$, K. A. Langley ${ }^{22}$, G. Leitchenkov ${ }^{23}$, C. Leuschen ${ }^{15}$, B. P. Luyendyk ${ }^{24}$,

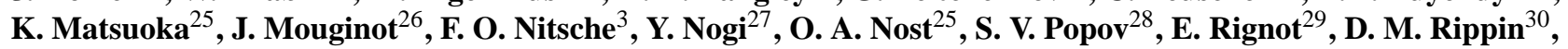
A. Rivera ${ }^{7}$, J. Roberts ${ }^{31}$, N. Ross ${ }^{32}$, M. J. Siegert ${ }^{2}$, A. M. Smith ${ }^{1}$, D. Steinhage ${ }^{18}$, M. Studinger ${ }^{33}$, B. Sun ${ }^{34}$,

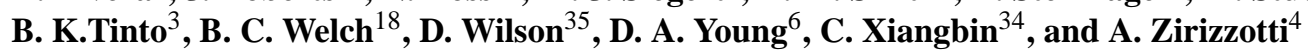

${ }^{1}$ British Antarctic Survey, Cambridge, UK

${ }^{2}$ School of Geographical Sciences, University of Bristol, UK

${ }^{3}$ Lamont-Doherty Earth Observatory of Columbia University, Palisades, USA

${ }^{4}$ Istituto Nazionale di Geofisica e Vulcanologia, Rome, Italy

${ }^{5}$ School of Geosciences, University of Aberdeen, UK

${ }^{6}$ Institute for Geophysics, University of Texas at Austin, USA

${ }^{7}$ Centro de Estudios Cientificos, Santiago, Chile

${ }^{8}$ Laboratoire de Glaciologie, Université Libre de Bruxelles, Brussels, Belgium

${ }^{9}$ Earth and Space Sciences, University of Washington, Seattle, USA

${ }^{10}$ Department of Geography, Swansea University, Swansea, UK

${ }^{11}$ Federal Institute for Geosciences and Natural Resources, Hannover, Germany

${ }^{12}$ National Space Institute, Technical University of Denmark, Denmark

${ }^{13}$ National Institute of Polar Research, Tokyo, Japan

${ }^{14}$ Jet Propulsion Laboratory. California Institute of Technology, Pasadena, USA

${ }^{15}$ Electrical Engineering \& Computer Science, University of Kansas, Lawrence, USA

${ }^{16}$ Stockholm University, Stockholm, Sweden

${ }^{17}$ St. Olaf College, Northfield, MN 55057, USA

${ }^{18}$ Alfred Wegener Institute, Bremerhaven, Germany

${ }^{19}$ Norwegian Polar Institute, Fram Centre, Troms $\varnothing$, Norway

${ }^{20}$ NASA Wallops Flight Facility, Virginia, USA

${ }^{21}$ College of Science, University of Canterbury, Christchurch, New Zealand

${ }^{22}$ Department of Geosciences, University of Oslo, Norway

${ }^{23}$ Institute for Geology and Mineral Resources of the World Ocean, St.-Petersburg, Russia

${ }^{24}$ Earth Research Institute, University of California in Santa Barbara, USA

${ }^{25}$ Norwegian Polar Institute, Tromso, Norway

${ }^{26}$ Department of Earth System Science, University of California, Irvine, USA

${ }^{27}$ National Institute of Polar Research, Tokyo, Japan

${ }^{28}$ Polar Marine Geosurvey Expedition, St.-Petersburg, Russia

${ }^{29}$ School of Physical Sciences, University of California, Irvine, USA

${ }^{30}$ Environment Department, University of York, Heslington, York, YO10 5DD, UK

${ }^{31}$ Department of Sustainability, Environment, Water, Population and Communities, Australian Antarctic Division, Hobart, Tasmania, Australia

${ }^{32}$ School of Geography, Politics and Sociology, Newcastle University, Newcastle upon Tyne, NE1 7RU, UK 


\author{
${ }^{33}$ NASA Goddard Space Flight Center, Greenbelt, USA \\ ${ }^{34}$ Polar Research Institute of China, Shanghai, China \\ ${ }^{35}$ Institute for Crustal Studies, University of California in Santa Barbara, USA \\ *These authors contributed equally to this work.
}

Correspondence to: P. Fretwell (ptf@bas.ac.uk)

Received: 31 July 2012 - Published in The Cryosphere Discuss.: 11 October 2012

Revised: 17 January 2013 - Accepted: 23 January 2013 - Published: 28 February 2013

\begin{abstract}
We present Bedmap2, a new suite of gridded products describing surface elevation, ice-thickness and the seafloor and subglacial bed elevation of the Antarctic south of $60^{\circ} \mathrm{S}$. We derived these products using data from a variety of sources, including many substantial surveys completed since the original Bedmap compilation (Bedmap1) in 2001. In particular, the Bedmap2 ice thickness grid is made from 25 million measurements, over two orders of magnitude more than were used in Bedmap1. In most parts of Antarctica the subglacial landscape is visible in much greater detail than was previously available and the improved datacoverage has in many areas revealed the full scale of mountain ranges, valleys, basins and troughs, only fragments of which were previously indicated in local surveys. The derived statistics for Bedmap2 show that the volume of ice contained in the Antarctic ice sheet $\left(27\right.$ million $\left.\mathrm{km}^{3}\right)$ and its potential contribution to sea-level rise $(58 \mathrm{~m})$ are similar to those of Bedmap1, but the mean thickness of the ice sheet is $4.6 \%$ greater, the mean depth of the bed beneath the grounded ice sheet is $72 \mathrm{~m}$ lower and the area of ice sheet grounded on bed below sea level is increased by $10 \%$. The Bedmap2 compilation highlights several areas beneath the ice sheet where the bed elevation is substantially lower than the deepest bed indicated by Bedmap1. These products, along with grids of data coverage and uncertainty, provide new opportunities for detailed modelling of the past and future evolution of the Antarctic ice sheets.
\end{abstract}

\section{Introduction}

It is more than a decade since grids of ice-surface elevation, ice thickness and subglacial topography for Antarctica were presented by the BEDMAP Consortium as digital products (hereafter we refer to these products collectively as Bedmap1, Lythe et al., 2001), and as a printed map (Lythe et al., 2000). Since then, Bedmap1 products have been widely used in a variety of scientific applications, ranging from geological (e.g., Jamieson et al., 2005) and glaciological modelling (e.g., Wu and Jezek, 2004), to support for geophysical data interpretation (e.g., Riedel et al., 2012), as a basis for tectonic interpretation (e.g., Eagles et al., 2009), as a baseline for comparison of newly-acquired subglacial in- formation (e.g., Welch and Jacobel, 2003), and even to help improve understanding of the distribution of marine species (Vaughan et al., 2011).

Like their predecessors (e.g., Drewry and Jordan, 1983), Bedmap1 products were based on a compilation of data collected by a large number of researchers using a variety of techniques, with the aim of representing a snap-shot of understanding, and as such, Bedmap1 has provided a valuable resource for more than a decade. However, in recent years, inconsistencies (such as negative water column thickness beneath some ice-shelf areas) in Bedmap1 have proved to be limitations and several new versions have been developed (e.g., Le Brocq et al., 2010; Timmerman et al., 2010), which have proved very useful to the community. Since Bedmap1 was completed, a substantial quantity of ice-thickness and subglacial and seabed topographic data have been acquired by researchers from many nations. The major improvement in coverage and precision that could be achieved by incorporating these data into a single new compilation is obvious. Here we present such a compilation, Bedmap2, which maintains several useful features of Bedmap1, but provides many improvements; higher resolution, orders of magnitude increase in data volume, improved data coverage and precision; improved GIS techniques employed in the gridding; better quality assurance of input data; a more thorough mapping of uncertainties; and finally fewer inconsistencies in the gridded products.

\section{General philosophy of approach}

The general approach used to derive the Bedmap2 products was to incorporate all available data, both geophysical and cartographic, and in particular, we endeavoured to include all measurements available to date. However, it should be noted that the disparities between varied input data sources, the inhomogeneous spatial distribution of data, and its highlyvariable reliability, means that we needed to develop a rather complicated, multi-stepped process of automatic GIS analyses and manual intervention (summarised in Fig. 1). Below, we describe the steps of these processes in detail. Some steps required specific judgments to be made with regard to conflicting measurements, with the consequence that not all measurements are honoured. 


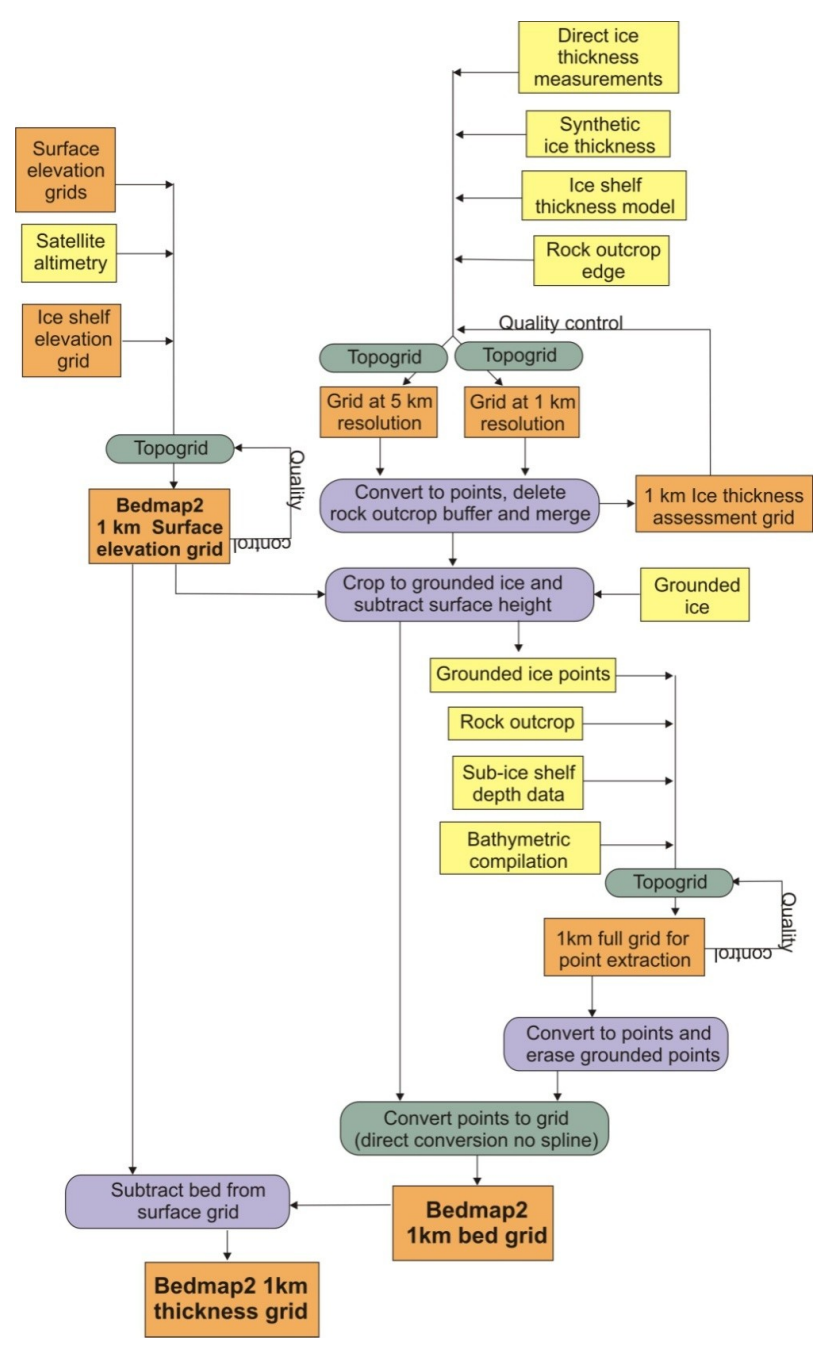

Fig. 1. Flow diagram of steps to construct the three Bedmap2 grids. Yellow boxes indicate vector data, orange represent gridded datasets, purple represent processes and green gridding. The three bold Bedmap2 boxes show the final outputs.

We took care, however, to ensure self-consistency in the ice-surface, ice-thickness, and bed-elevation grids, and consistency between the specific values in these grids and the known flotation/grounded condition of the ice in particular regions.

The aim of the Bedmap2 project was to produce a complete product covering the entire continent, which would be appropriate for use in a wide range of scientific disciplines, and this has dictated the choice of processes employed. For example; as with Bedmap1, the gridding techniques used in deriving Bedmap2 relied solely on input data and general assumptions about the nature of the ice-surface and sub-glacial landscape. They did not rely on ice-flow assumptions that could improve performance in areas with limited data (Le Brocq et al., 2008b; Morlighem et al., 2011; Roberts et al.,
2011), but which would preclude their use in many glaciological analyses.

\section{Grounding line, coastline, ice shelf limits, geoid and projection}

To ensure that Bedmap2 grids provide a self-consistent product where the bed-elevation in all grounded areas is equal to ice-surface minus ice-thickness, and in all areas of floating ice shelf, ice-bottom (ice-surface minus ice-thickness) is above the bed-topography, we require defined domains of grounded ice sheet, floating ice shelves and open sea. In theory, these could be extracted from sufficiently accurate grids of ice thickness, surface elevation and bed elevation, but in reality, using the known distribution of floating ice provides extra control on the derivation of the gridded products. We combined a grounding line delineated from MODIS imagery (Haran et al., 2005) with one interpreted from satellite SAR interferometry (Rignot et al., 2011). In general, we favoured the latter in all locations where good satellite data were available, and where multiple grounding lines arose from the SAR interferometry we used the most seaward line. The exception to this was Pine Island Glacier, where an intermediate grounding line from the year 2000 corresponded most closely in acquisition date with the majority of the radar sounding data in the compilation. From these sources, we created a $1 \mathrm{~km}$ gridded mask to define the limit of grounded ice in Antarctica.

To define the seaward limit of the ice shelves, we used the MODIS-derived limits as of 2003/4 (Bohlander and Scambos, 2007). As an absolute reference for elevation, we used the GL04C geoid (Forste et al., 2008) throughout, and for the grid products, we used Polar Stereographic projection (Snyder, 1987) based on the WGS84 ellipsoid, with true scale at $71^{\circ} \mathrm{S}$. For area and volume calculations, we used the Lambert Azimuthal Equal Area projection (Snyder, 1987).

\subsection{Note on grid resolution}

We provide the ice thickness, bed and surface elevation grids at a uniform 1-km spacing. In creating the ice thickness grid, however, we initially gridded the direct measurements of thickness at $5 \mathrm{~km}$, primarily because the distribution of these direct measurements does not warrant a higher resolution (Fig. 2). Indeed, even with 5-km grid cells, only $33 \%$ of cells contain data and reducing the grid spacing would reduce this fraction and result in more "bulls-eyes" around individual data points (erroneous artefacts around isolated data points where lack of nearby data causes the gridding algorithm to over emphasise a single point). Few areas (some on the Antarctic Peninsula and Pine Island Glacier) have sufficiently dense surveys to justify finer gridding: for example, the recent AGAP survey (Bell et al., 2011) collected over three million data points, but also has a nominal spacing 


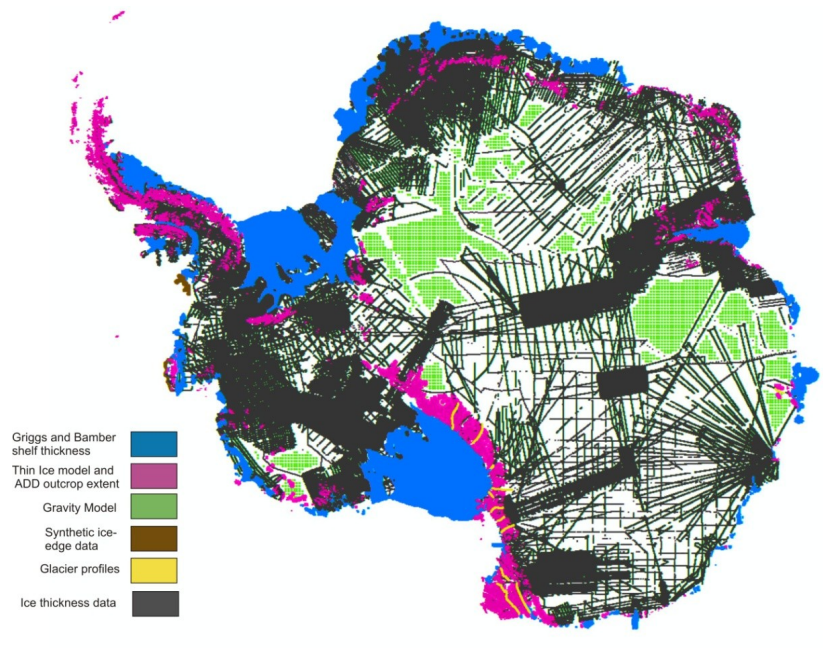

Fig. 2. Coverage of datasets used in the construction of the ice thickness grids.

between flight lines of $5 \mathrm{~km}$. To better capture the complexity of rock outcrop and mountainous areas, though, we used a finer $1-\mathrm{km}$ grid spacing in areas within $10 \mathrm{~km}$ of rock outcrop. This renders the mountain ranges particularly well and this high level of detail has been maintained in the subsequent bed model. The final $1 \mathrm{~km}$ ice thickness grid is the combination of the thickness from these $5 \mathrm{~km}$ and $1 \mathrm{~km}$ grids, rendered at $1 \mathrm{~km}$.

\section{Derivation of the ice-thickness grid}

The Bedmap2 ice thickness grid, subtracted from the surface elevation (see following section), allows us to map the bed topography of the grounded part of the ice sheet and it also provides a continuous representation of both the grounded ice sheet and floating ice shelves. To grid thickness, we broadly followed the methodology set out in Bedmap1. The primary data sources comprised of direct ice thickness measurements (largely from airborne radar surveys), a grid of iceshelf thickness derived from satellite altimetry measurements of freeboard (Griggs and Bamber, 2011), and rock-outcrop boundaries that define isopleths of zero ice thickness (Scientific Committee on Antarctic Research, 2012). In areas where primary data were unavailable, we estimated thickness using a satellite-derived gravity field, and in some places, we generated "synthetic" thickness data to ensure consistency of the grid with known topographic features and ice-flotation.

\subsection{Direct ice thickness measurements}

The database of direct ice thickness measurements compiled for Bedmap2 is ten times larger than that for Bedmap1. The Bedmap1 data were acquired using a variety of methods and often were not located with the high accuracy possible with modern GPS, and so the variable quality of the input data was a considerable issue (Lythe et al., 2001). The great majority of data collected since then have been acquired using airborne radar sounding located using high-quality GPS, with positions precise to within a few metres. The locations of new data acquired in this way have been used without further accuracy checks, except where the gridding procedure highlighted obvious errors.

In addition to airborne radar surveys, direct thickness measurements also come from over-snow radar (e.g., King et al., 2009) and seismic sounding data (e.g., Smith et al., 2007) that are highly precise in position and have measurement accuracy at least as good as the airborne radar data.

With the dominance of airborne radar sounding in the new datasets, along with improved storage and automated processing, the density of individual thickness points or "picks" is typically much greater than previously. This increased sampling density and the move towards larger airborne campaigns mean that several recent surveys used in Bedmap2 each include as many points as the whole of the Bedmap1 compilation (see Table S1).

Table S1 shows the sources of newly acquired data used to grid ice thickness. The new datasets come from 83 survey campaigns. Many are freely available for download (e.g., http://nsidc.org/data/), while others are presented in summary publications (e.g., Ross et al., 2012), but remain unpublished in their raw form. The total number of survey points used in the thickness compilation of Bedmap2 is 24.8 million, which compares to 1.4 million in Bedmap1. Furthermore, improvements in the capability of the GIS software and hardware have allowed all of these data to be incorporated in the gridding process. In Bedmap1, filtering and decimation were required, reducing the dataset to $\sim 140000$ points.

The majority of direct ice thickness measurements from radar and seismic techniques were calculated with the inclusion of a "firn correction". Routinely for radar measurements on thick ice, $10 \mathrm{~m}$ of additional ice thickness has been added by researchers to account for the low-density/high-velocity firn layers. For seismic measurements, a similar correction is made for the low-density/low-velocity firn layers. The icethickness measurements compiled for Bedmap2, thus, represent the researchers' best estimate of the physical ice thickness, rather than an "ice-equivalent" thickness. For much of the data used in Bedmap1, the exact value of the firn correction applied could not be determined, but we assume that the researchers collecting the data were best placed to determine the appropriate firn correction, and we have not attempted any further homogenisation.

Not only has the volume of data available in Bedmap2 increased, its geographical coverage is also much extended. The number of 5-km cells that contain data has approximately doubled between the two compilations, from 82000 (17\% of the grounded bed) to 173000 (36\%, of the 


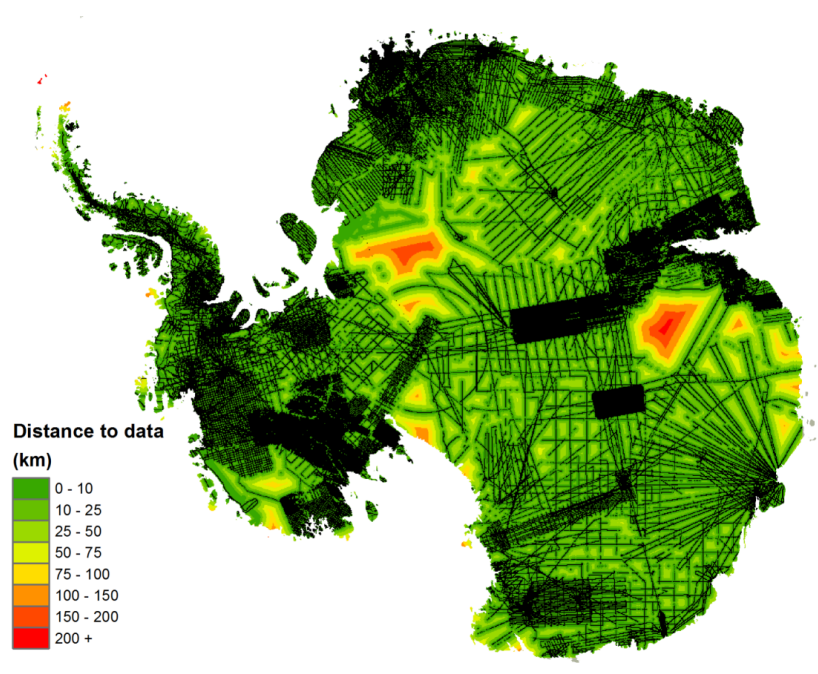

Fig. 3. Primary data coverage (black lines) and nearness to ice thickness data.

grounded bed). The number of cells within $20 \mathrm{~km}$ of measured ice thickness is now $83 \%$. There are still, however, large areas where no data exist and many more where the data density is poor. Figure 3 shows the distribution of ice thickness measurements over grounded ice, with colours of unsampled cells showing the distance to the nearest data. This highlights two particular areas, between Recovery and Support Force glaciers and in Princess Elizabeth Land (see Fig. 4 for locations mentioned in the text), where direct measurements of ice-thickness are still entirely absent. Here measurements are urgently needed to reduce uncertainty in bed topography and the calculated ice volumes. Several smaller areas in western Marie Byrd Land also have large data gaps (Fig. 3), while in Enderby Land, the existing data come from older surveys that produced low data-density and had potentially poor accuracy, resulting in relatively large cross-track errors in the gridded data.

For most of the ice sheet, we have assumed that changes in the ice thickness field through time were insignificant relative to the measurement uncertainty and so used measurements regardless of their acquisition date. Given that the vast majority of data were collected in the last two decades, and the rates of thickness change across Antarctic are in most places low (Pritchard et al., 2009), this assumption is generally reasonable. However, in the lower $35 \mathrm{~km}$ of Pine Island Glacier, we excluded data from a recent (2011) survey because the rapid thinning of this glacier meant that the ice thickness had reduced by $\sim 40 \mathrm{~m}$ or $3 \%$ of the total thickness relative to more extensive earlier surveys.

\subsection{Thickness of ice shelves}

A single gridded dataset of ice thickness derived from satellite altimetry (Griggs and Bamber, 2011) provided full cov-

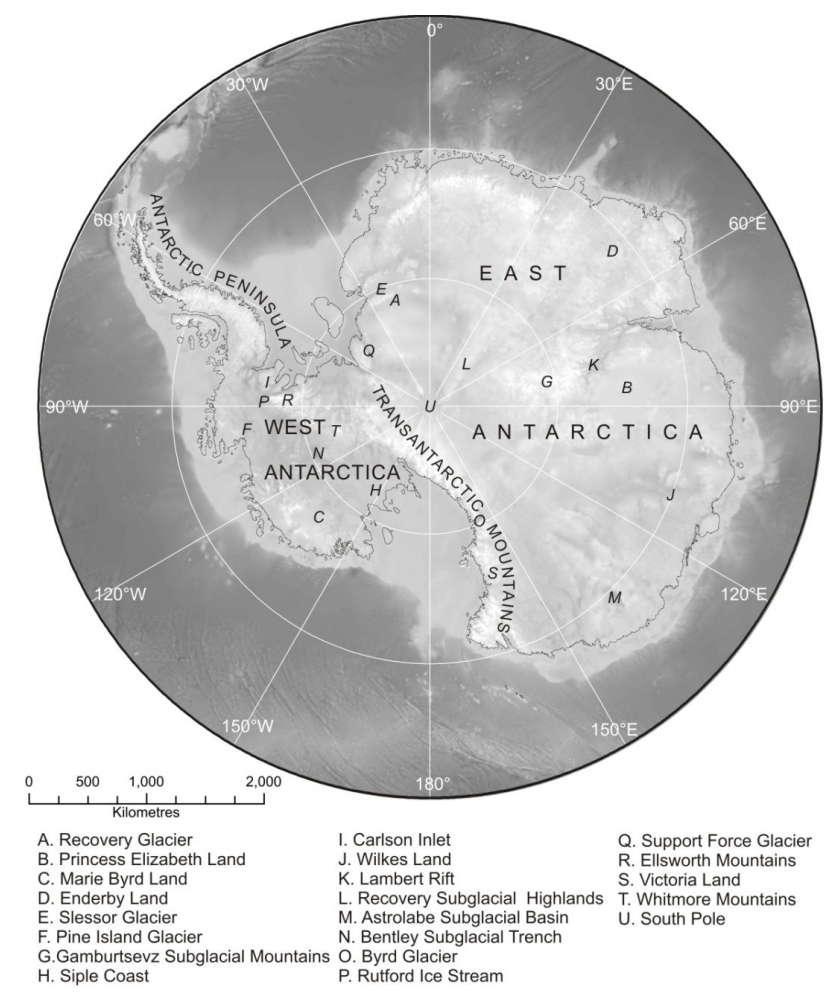

Fig. 4. Places mentioned in the text.

erage and uniform consistency of all the significant floating ice shelves around Antarctica. This was adopted as the primary ice-thickness data source for these regions. We excluded data from areas found to be grounded (Rignot et al., 2011) and, in order to minimise bias introduced by failure of the assumption of hydrostatic equilibrium, we excluded data within $5 \mathrm{~km}$ of the grounding line in most areas, extending to $10 \mathrm{~km}$ over ice-stream grounding zones (Griggs and Bamber, 2011). Where possible, we used airborne radar thickness measurements for these exclusion areas in our interpolation. We edited out abrupt spike, pit and step artefacts and adjusted the thickness of some ice shelves where the altimetry-derived thickness away from the grounding line disagreed with that from radar surveys. Where recent and extensive firn-corrected radar data indicated a disagreement, we calculated the mean difference between the two datasets at all of the radar measurement points and, for individual ice shelves, uniformly adjusted the altimetry-derived thickness grid by this value. This gives a zero mean difference in radarand altimetry-derived thickness while preserving the detailed spatial variability of the altimetry-derived dataset (Table 1 ). This process renders ice shelf thickness consistent with the radar-measured thickness on the adjacent grounded ice. For Nivlisen Ice Shelf, an extensive radar dataset disagreed with the altimetry in mean ice thickness and thickness distribution so, for that ice shelf, we gridded ice shelf thickness directly from the radar data. 
Table 1. Corrections applied to altimetry-derived ice shelf thickness (Griggs and Bamber, 2011) to match direct measurements of ice thickness.

\begin{tabular}{ll}
\hline & $\begin{array}{l}\text { Correction to mean } \\
\text { thickness applied } \\
(\mathrm{m})\end{array}$ \\
\hline Vigridisen & -62 \\
17 East Ice Shelf & -18 \\
Fimbulisen & -16 \\
Quarisen, Ekströmisen and Jelbartisen & -30 \\
Brunt Ice Shelf /Stancomb-Wills Ice Stream & -4 \\
Venable Ice Shelf & -60 \\
Pine Island Glacier (main shelf) & -21 \\
Pine Island Glacier (north) & -21 \\
Thwaites Ice Tongue & -81 \\
Crosson Ice Shelf & -64 \\
Dotson Ice Shelf & -48 \\
Getz Ice Shelf & -48 \\
Totten Glacier outer shelf & -59 \\
(north of $67^{\circ}$ S) & \\
George VI Ice Shelf & +80 \\
(north of $71.5^{\circ}$ S) & \\
George VI Ice Shelf (zone stretching & +100 \\
$55 \mathrm{~km}$ southwest of $71.5^{\circ} \mathrm{S}$ ) & \\
George VI Ice Shelf (zone stretching & +60 \\
from $55 \mathrm{~km}$ to $135 \mathrm{~km}$ southwest of $\left.71.5^{\circ} \mathrm{S}\right)$ & \\
George VI Ice Shelf (southernmost $35 \mathrm{~km}$ ) & +30 \\
\hline
\end{tabular}

\subsection{Gravity-derived ice thickness}

For the two large areas lacking direct thickness data (between Recovery and Support Force glaciers and in Princess Elizabeth Land), we used satellite gravity data as an indirect indication of ice thickness. Before radio echo sounding of ice thickness became routine, free-air gravity measurements were commonly used to aid interpolation between seismic ice thickness soundings (e.g., Bentley, 1964). The correlation of free-air gravity and topography continues to be used to provide regional bathymetric maps from satellite gravity data (Smith and Sandwell, 1997). Nowadays, the longer wavelength free-air gravity field of the entire Antarctic continent has been derived from satellite gravity missions such as GRACE (Tapley et al., 2004) and GOCE (http://www.esa.int/ SPECIALS/GOCE/index.html). By inverting this long wavelength gravity field, we can place constraints on the regional scale subglacial topography.

Early workers estimated sub-ice topographic variation by assuming a linear gravity topography conversion factor (GTCF) of $13.5 \mathrm{~m} \mathrm{mGal}^{-1}$, based on a Bouguer slab approximation with rock and ice densities of $2670 \mathrm{~kg} \mathrm{~m}^{-3}$ and $900 \mathrm{~kg} \mathrm{~m}^{-3}$, respectively (Kapitsa, 1964). Bentley (1964) noted that the true GTCF will be a complex function of distance to bed, bed morphology, rock density and regional isostatic balance, and used sparse seismic soundings and associated gravity measurements to calculate an empirical GTCF of
$20 \mathrm{~m} \mathrm{mal}^{-1}$. Additionally, by considering the change in calculated gravity between seismic tie points, the effects of isostatic compensation on the result were minimised. We have extended this empirical technique to invert satellite gravity data for regional subglacial topography in the two areas described above.

Firstly, we compared down-sampled 20-km topography and GOCE 2010 satellite gravity data within windows of $300 \times 300 \mathrm{~km}$. We calculated the correlation between gravity and topography by fitting a first-order least squares polynomial through the windowed data. The slope of the polynomial was taken as an empirically derived GTCF, while the intercept indicates a bias, most likely due to the degree of regional isostatic compensation. Assuming the GTCF and level of isostatic compensation vary on longer spatial wavelengths than does the subglacial topography, we extrapolate the resulting values to areas where the subglacial topography is not known using a tensioned spline gridding technique (tension 1), and $300-\mathrm{km}$ cosine filter to smooth the resulting grids. We then inverted the regional subglacial topography by multiplying the satellite gravity field by the extrapolated empirical GTCF and adding the measured bias.

Results show GTCF values close to the theoretical ideal of $13.5 \mathrm{~m} \mathrm{mal}^{-1}$ over much of the Antarctic continent, with locally higher values, around $20 \mathrm{~m} \mathrm{mal}^{-1}$, associated with the elevated topography of the Transantarctic Mountains, as suggested by earlier authors. In the vicinity of Support Force Glacier, a series of linear basins 500 to $1000 \mathrm{~m}$ deep are indicated. The true basins in this area are likely to be narrower and deeper, as we describe in our discussion of uncertainty (see below). However, inversion of gravity data does provide a 1st-order approximation of the subglacial topography in this region. In the Bedmap2 thickness grid, we used gravity derived thickness in areas that were more than $50 \mathrm{~km}$ from direct ice-thickness measurements.

\subsection{Synthetic ice thickness data}

The first synthetic dataset was required to prevent rock outcrops (with isopleths of zero ice thickness) from overly skewing the ice thickness distribution in mountainous areas with few direct measurements. Here we applied a "thin-ice" model (similar to that applied in Bedmap1, Lythe et al., 2001). This model relies on the assumption that in mountainous areas where ice fills the valleys, there is a general correlation between ice thickness and the distance from rock outcrops. In areas within $10 \mathrm{~km}$ of rock outcrop and greater than $10 \mathrm{~km}$ from radar data, we employed the thin ice model following the procedure laid out in Bedmap1. Identical regression coefficients ( $y=223.98 \operatorname{Ln}(x)-1108.4)$, originally calculated from bed data near rock outcrop in Prince Charles Land and Dronning Maud Land were applied. The following modifications were made to the original thin ice model: (1) The vector data used to describe the rock outcrops was taken from an updated digital dataset (Scientific Committee on 
Antarctic Research, 2012); (2) We refined the modelled ice thickness by calibrating the rate at which thickness increases with distance for different mountain areas for which radar data were available. This change particularly affected mountainous coastal areas where uncalibrated ice thickness from the thin-ice model tended to be excessive.

The second synthetic dataset was required to define major glaciers passing through mountain ranges for which icethickness measurements are too sparse to ensure their existence in the gridded product (cf., Lythe et al., 2001). The absence of such topographic troughs in the Bedmap2 products would have severely limited the value to the ice-sheet modelling community. The synthetic glacier profiles are linear interpolations, along the centre profile of the glacier, between the nearest upstream and downstream data points, or a downstream data point at the grounding line calculated by hydrostatic equilibrium from the surface height. The specific glaciers for which such data were included are shown in Fig. 2. These differ from those in Bedmap1 because some glaciers have since been surveyed and because we added new ones in mountainous areas of East Antarctica and the Antarctic Peninsula.

\subsection{Gridding of ice-thickness}

Various algorithms have previously been used to grid the topography of glaciated landscapes, but the morphology of such environments, when combined with the irregular, often highly anisotropic distribution of ice thickness measurements (lines of densely sampled point measurements separated by many kilometres) tends to produce characteristic gridding artefacts. These artefacts commonly include "bullseyes" around isolated points and "chaining" where survey tracks cross narrow linear features such as valleys. Bedmap1 employed an inverse-distance-weighting algorithm with an octal search. For Bedmap2, where the data volume has increased substantially, we completed a series of tests to select the most appropriate algorithm.

Specifically, we used a detailed, 90-m gridded Shuttle Radar Topography Mission (SRTM) DEM of the now icefree glaciated landscape of the Scottish Highlands, mosaiced with GEBCO Antarctic bathymetry to produce a seamless DEM. We reproduced a typical sampling distribution by laying over this DEM a sample of points from actual Bedmap2 survey lines from a section of the central Antarctic Peninsula, complete with defined rock outcrops, thin-ice-modelled synthetic data and ice shelf thickness. We sampled the height of the Scotland DEM at the locations of the overlaid points and gridded this sample with the nearest neighbour, cubic spline, bilinear spline, kriging (with several different semivariograms), triangular irregular network (tin) and Topogrid algorithms (available within ESRI Ltd, ArcGIS 9). For each sample, we constructed a $5-\mathrm{km}$ bed model as if the survey points extracted from the Scotland DEM were measurements from subglacial bed elevation. We compared the output grid with the original SRTM DEM resampled to $5 \mathrm{~km}$ (Table 2).

The best results were returned by the ArcGIS Topogrid routine, designed around the ANUDEM algorithm (Hutchinson, 1988), which had a standard deviation of $66 \mathrm{~m}$ compared to $85 \mathrm{~m}$ and $86 \mathrm{~m}$ for spline-with-tension and IDW, respectively. Topogrid is an adapted thin plate spline with an iterative finite difference interpolation that imposes constraints upon the elements to prevent spurious sinks being formed in the output dataset (Hutchinson, 1989). It is routinely and widely used in bathymetric applications (Jakobsson et al., 2000) and digital cartography (e.g., British Antarctic Survey Misc series maps have all used this technique). There are a number of options available within the Topogrid function in ArcGIS: for our test and final grids we used no drainage enforcement, set the primary data type to "spot" and, after experimentation, left the maximum number of iterations and roughness penalty as the default as both these options had minimal effect on the final output.

\section{Compilation of ice-surface elevation grid}

To derive bed elevation from ice thickness over the grounded ice sheet requires a reliable grid of elevation for the ice surface and exposed rock outcrops. Several DEMs covering all (e.g., Bamber et al., 2009a) or part of Antarctica (Cook et al., 2012) are available, and these vary in quality, accuracy and consistency. We have combined several DEMs in order to exploit the strengths of each, which we determined from published sources (see Fig. 5). We quantitatively checked the resulting surface-elevation grid by comparison to airborne altimetry and satellite laser altimetry (ICESat), and by comparing the form of gridded elevation surfaces to the form of the surface shown by high-resolution visible satellite imagery (Haran et al., 2005; Bindschadler et al., 2008).

For much of the ice sheet, we used an extensive and consistent surface elevation model derived primarily from satellite radar altimetry (Bamber et al., 2003), which is highly accurate over areas of low surface slope, but less accurate over areas of higher surface slope, and is not reliable in areas of mountainous terrain and widespread rock outcrop (Le Brocq et al., 2010).

In mountainous areas of West and East Antarctica within $10 \mathrm{~km}$ of rock outcrops, we use the Ohio State University DEM (OSU DEM) (Liu et al., 1999), which was based primarily on vector data from the Antarctic Digital Database (Scientific Committee on Antarctic Research, 2012), which in turn is based upon cartographic information. This DEM provides detailed elevation data over rock, but performs poorly over ice sheets and in some places has known positional errors of $>10 \mathrm{~km}$.

In some coastal and mountainous areas in East and West Antarctica and over the Antarctic Peninsula, we use the ICESat-derived NSIDC DEM (DiMarzio et al., 2007). This 
Table 2. Comparative analysis of the best results from a selection of gridding methods. Each method was tested for gridding accuracy against a high-resolution digital elevation model of a previously glaciated landscape (the Scottish Highlands) using a sample of spot heights extracted on the highly irregular pattern of data collection provided by a sub-sample of the Bedmap2 flight-lines. These results show that Topogrid out-performed other gridding techniques in areas where data were present, and also had high accuracy over the grid as a whole.

\begin{tabular}{|c|c|c|c|c|c|c|c|c|c|}
\hline Gridding algorithm & $\min$ & $\max$ & mean & std dev & skew & kurtosis & $\begin{array}{r}1 \mathrm{st} \\
\text { quartile }\end{array}$ & median & $\begin{array}{r}3 \text { rd } \\
\text { quartile }\end{array}$ \\
\hline \multicolumn{10}{|c|}{ Elevation difference between sampled spot heights and the grid of elevation derived from these spot heights } \\
\hline Topogrid & -750 & 522 & 1.4952 & 97.224 & -0.609 & 6.7704 & -36 & 5 & 46 \\
\hline spline with tension & -820 & 797 & -5.801 & 113.6 & -0.175 & 7.7277 & -47 & -2 & 38 \\
\hline IDW & -820 & 744 & -4.028 & 109.41 & -0.15 & 7.8096 & -42 & -1 & 37 \\
\hline Rasterized TIN & -796 & 689 & -3.314 & 114.31 & -0.239 & 7.2387 & -46 & -1 & 41 \\
\hline \multicolumn{10}{|c|}{ Elevation difference between the grid derived from sampled spot heights and the original high-resolution DEM } \\
\hline Topogrid & -409 & 329 & -0.587 & 66.256 & -0.369 & 7.4475 & -28 & 1 & 30 \\
\hline spline with tension & -387 & 564 & -3.537 & 85.376 & 0.349 & 6.7709 & -43 & -4 & 34 \\
\hline IDW & -403 & 504 & -3.244 & 86.051 & 0.142 & 5.8126 & -42 & -3 & 35 \\
\hline Rasterized TIN & -202 & 349 & -3.521 & 52.728 & 1.526 & 8.4427 & -31 & -12 & 13 \\
\hline
\end{tabular}

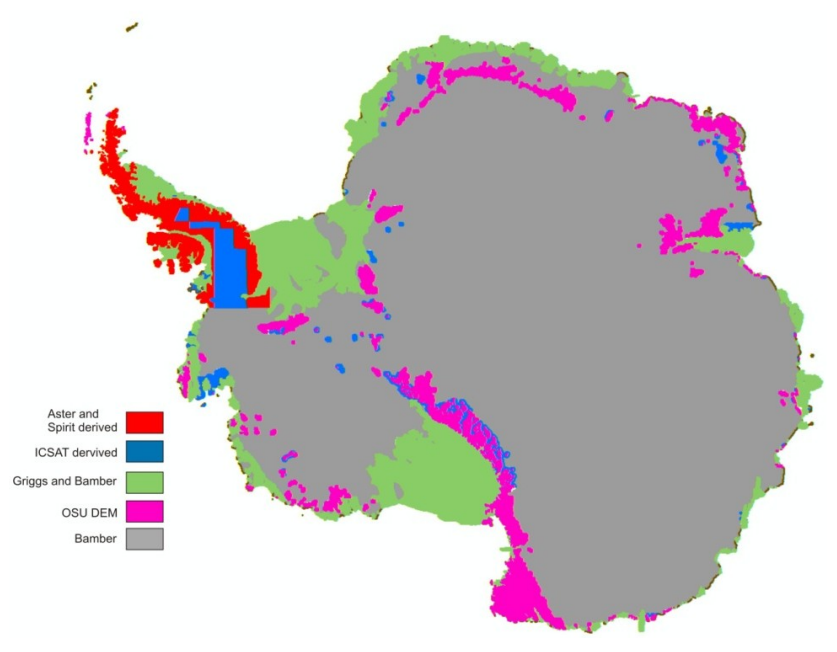

Fig. 5. Coverage of datasets used in construction of the surface grid.

performs well in areas densely sampled by ICESat, but less well elsewhere. On the Antarctic Peninsula, we augmented this DEM with two photogrammetrically complied DEMs, from the SPIRIT project (SPOT satellite images) (Korona et al., 2009) and GDEM (from ASTER satellite images) (Korona et al., 2009; Cook et al., 2012). Photogrammetrically compiled DEMs perform well on high-contrast surfaces, particularly on rocky north facing slopes, but in flat, featureless areas the lack of contrast makes automated DEM production by photogrammetric techniques subject to larger errors and the two products tend to perform less well in flat icy terrain and in shadowed areas.

Over the ice shelves, we used the same satellite altimetryderived DEM used in the ice-thickness compilation (Griggs and Bamber, 2011), edited to remove step-like artefacts near some grounding lines, and where necessary, we filled gaps using ICESat (GLA12 release 28) satellite laser altimetry data corrected for saturation, cloud, ocean, earth and load tides and the inverse barometer effect (Pritchard et al., 2012). Over both ice shelves and ice sheet we removed pits and spikes resulting from occasional bad data points and corrected gross interpolation errors in topography where the form of the surface elevation failed to correspond to the form of the landscape visible in high-resolution Landsat and MODIS images (LIMA, MOA). In these areas, we re-gridded the surface using ICESat data and in some cases, manually defined ridge crests with linearly interpolated heights. On some stretches of coast, we added zero-value or interpolated heights to constrain poorly-sampled margins.

We deleted data in a 10-km no-data buffer between neighbouring datasets before gridding the multiple surface elevation datasets together (with ArcGIS Topogrid) to ensure smooth transitions between datasets and, in particular, across grounding zones. Thus, we created a seamless $1-\mathrm{km}$ grid of ice surface elevation for the entire continent. Where possible, we checked the accuracy of this DEM relative to geoidallyreferenced airborne altimetry data from the IceBridge mission (Leuschen and Allen, 2012).

We tested for areas of known grounded ice along the coast where the combination of measured ice thickness and surface elevation, firn thickness and firn density (Ligtenberg et al., 2011) implied floating. We found small areas up to $10 \mathrm{~km}$ inland that failed this test but we did not enforce grounding here because the areas are small relative to the resolution of the gridded firn properties, because the grounding line position may be imperfectly known or may move across a range of positions, and because a grounding zone may be subject to bridging stresses and flow effects that prevent ice from reaching hydrostatic equilibrium. 
We also tested for discontinuity artefacts in the surface elevation and thickness grids by calculating the basal driving stress from them and looking for abrupt changes associated with the boundaries of neighbouring datasets. Where necessary, we eliminated edge artefacts by allowing no-data buffers between the datasets used in the grid interpolation. In a small number of sites, possible artefacts remain, but these are difficult to verify or eliminate given the available data.

\section{Derivation of subglacial and seabed elevation grid}

Given the surface and ice-thickness grids described above it is conceptually simple to determine the bed elevation by subtraction. However, maintaining resolution in mountainous areas and creating a seamless topography incorporating open ocean bathymetry, sub-ice cavities and sub-glacial bathymetry required a multi-step approach (Fig. 1).

\subsection{Open ocean and coastal bathymetry}

Bedmap2 extends to $60^{\circ}$ South, well beyond the Antarctic coastline, incorporating large areas of continental shelf and deep ocean bathymetry in the grid of bed topography. For the majority of these areas, we mosaiced together (into a $1 \mathrm{~km}$ grid) the GEBCO 2008 bathymetric compilation with several publicly available datasets that superseded the 2008 compilation (Fig. 6). A considerable body of even newer swath bathymetry survey data are now available and the substantial task of compiling and gridding these datasets is being undertaken by the International Bathymetric Chart of the Southern Ocean (IBCSO) Consortium.

\subsection{Sub-ice shelf bathymetry}

For the sub-ice-shelf bathymetry, we used data from a recent compilation (Timmerman et al., 2010), along with data in the Bedmap1 database. The sea-bed topography beneath ice shelves is, in many areas, poorly constrained. Although the most recent data compilations have been integrated into Bedmap2 many areas still require better data for effective modelling. Better data in these sub-shelf areas are important for our understanding of Holocene ice retreat and the retreat of the LGM Antarctic Ice Sheet. We tested for areas where ice-shelf thickness and sub-shelf bathymetry falsely indicated grounded ice, and where necessary, enforced flotation by lowering the (poorly sampled) sea bed. We did this by interpolating the thickness of the sub-ice-shelf water column between the point where cavity thickness declined to $100 \mathrm{~m}$ and the grounding line where cavity thickness is $0 \mathrm{~m}$. This approach was required for Getz, Venable, Stange, Nivlisen, Shackleton, Totten and Moscow University ice shelves, for some of the thickest areas of the Filchner, Ronne, Ross, Amery ice shelves and for the ice shelves of Dronning Maud Land.

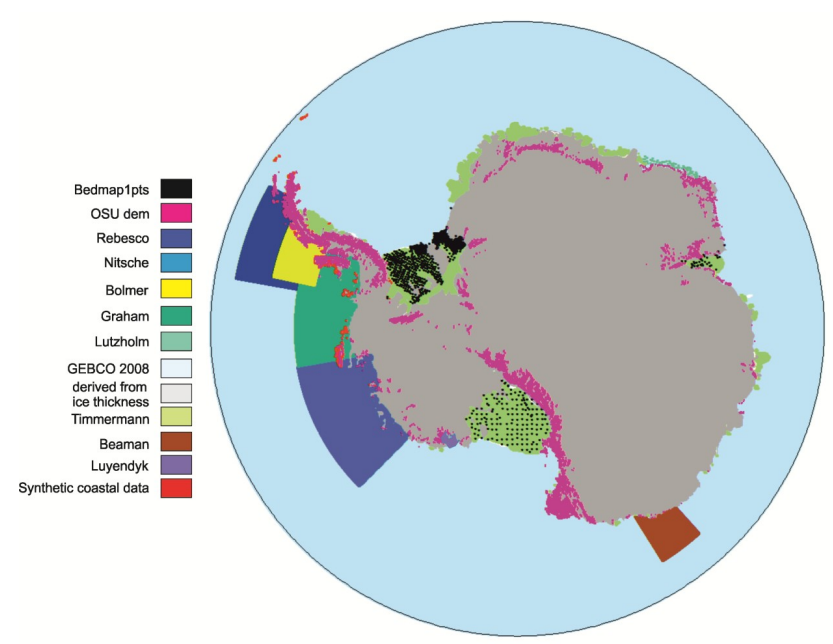

Fig. 6. Coverage of bathymetry and rock outcrop datasets used in the construction of the bed elevation grid. Datasets include a number of published grids including: Rebesco et al. (2006), Graham et al. (2011), Nitsche et al. (2007), Beaman (2010), Luyendyk et al. (2003), and Bolmer et al. (2008).

\subsection{The combined bed dataset}

We converted the ice thickness grids at $5 \mathrm{~km}$ and $1 \mathrm{~km}$ resolution to point datasets and in areas distant from rock outcrop, subtracted the resulting $5-\mathrm{km}$ ice-thickness points directly from the 1-km ice surface elevation model to give bed height. In areas within $10 \mathrm{~km}$ of rock outcrop, the thin-ice-model produced a denser coverage of synthetic ice thicknesses, so in these areas, 1-km thickness points were subtracted from the 1-km ice surface. From this point coverage, areas of rock outcrop (which would result in negative or zero ice thickness) were removed and replaced by surface model heights. The three grids thus constructed (far from rock outcrop, near to rock outcrop and within areas identified as rock outcrop) were combined with points derived from the ocean and subice-shelf bathymetry and gridded to produce one seamless $1 \mathrm{~km}$ grid of bed and sea-floor elevation.

\section{Results}

The three gridded outputs of surface, thickness and bed can be seen in Figs. 7, 8 and 9.

\subsection{Uncertainty in the Bedmap2 grids}

The Bedmap2 grids aim to provide representative values of surface height, ice thickness or bed elevation for each grid cell. The various measurements used and the gridding and interpolation processes have uncertainties and these accumulate in the bed elevation grid because it is combined from the surface elevation and ice thickness. The main sources of uncertainty include uncertainty in the surface DEM, direct ice 


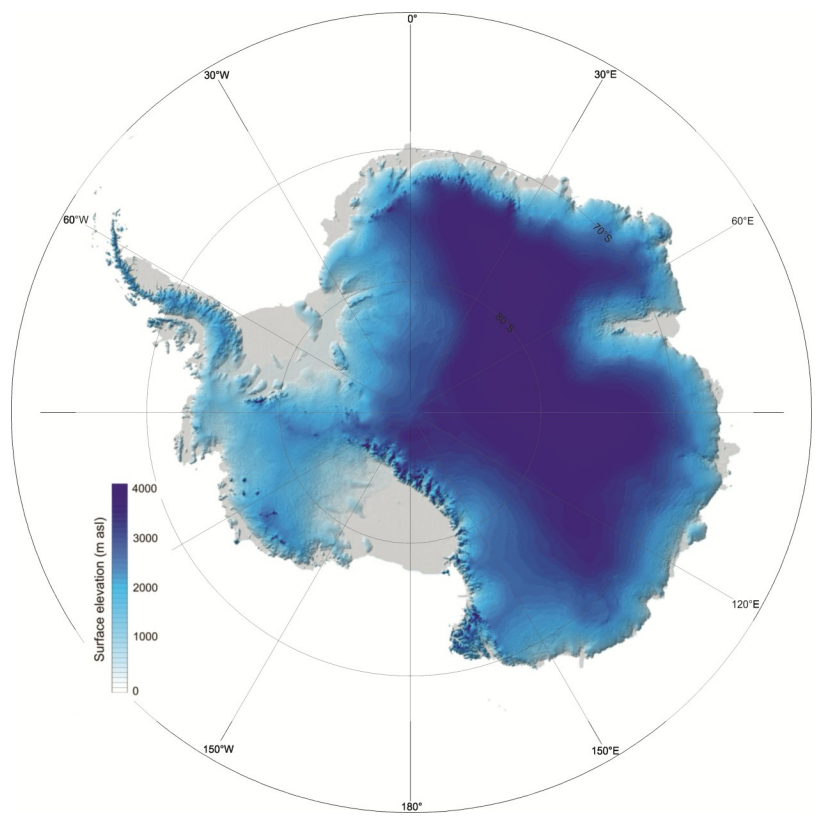

Fig. 7. Bedmap2 surface grid.

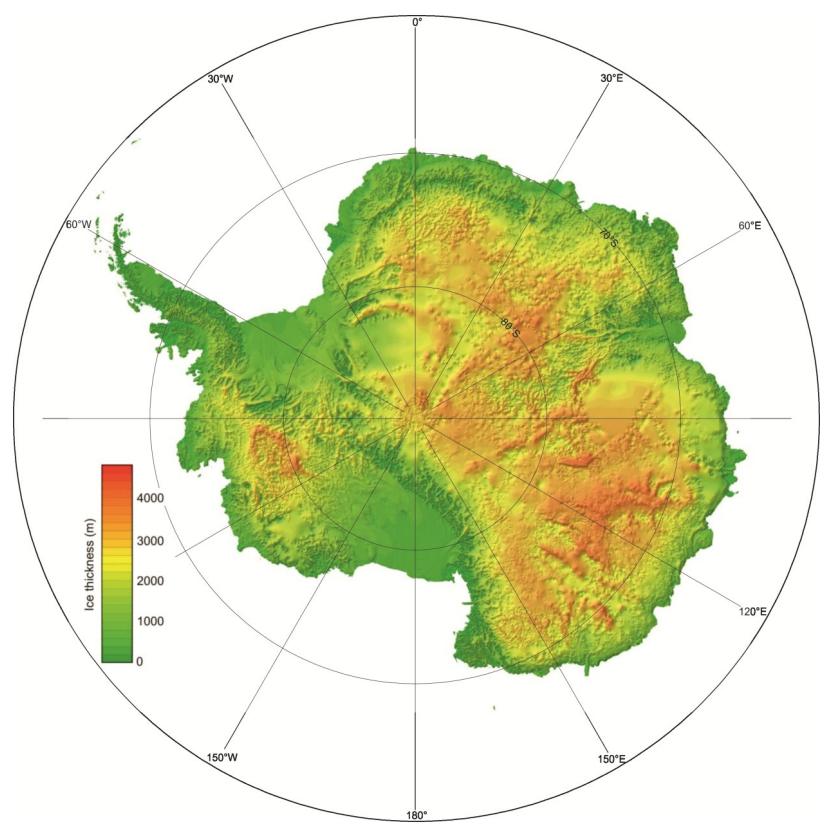

Fig. 8. Bedmap2 ice thickness grid.

thickness measurements, other constraints on ice thickness (ice shelf thickness from altimetry, gravity over ice sheets), synthetic data (thin-ice model, interpolated profiles), and the gridding and interpolation process.

\subsection{Surface DEM}

The surface DEMs used in the Bedmap2 surface elevation grid have published uncertainty estimates at their native res-

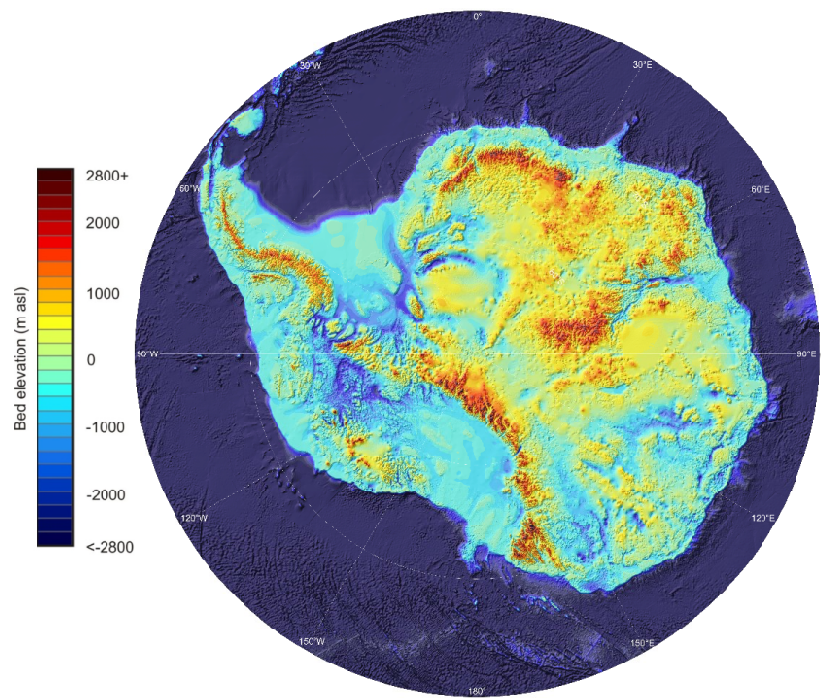

Fig. 9. Bedmap2 bed elevation grid. Although difficult to see at this scale, the bed elevation in areas where the main source of bed elevation data is gravimetric has inherited roughness from the surface grid.

olutions (Table 3). Accounting for bias and random errors, we assign an estimated $\pm 30 \mathrm{~m}$ uncertainty to the Bedmap2 surface elevation grid, rising to $\pm 130 \mathrm{~m}$ over mountains.

\subsection{Direct ice thickness measurements}

Over the ice sheets, older radar data that were included in the Bedmap1 compilation were often collected without the advantage of modern GPS control, therefore, the positional accuracy was usually poorer than for more recent data. A rigorous quality control procedure was used in the original compilation so, although the spatial accuracy of these data may be poorer than more recent acquisitions, these data are taken as pre-checked and are included without further investigation.

\section{Cross-over analysis}

We assessed radar survey cross-over differences on the full dataset prior to the final quality-control step to give a conservative estimate of measurement accuracy, and to give insights into the consistency of individual datasets and the uniformity between datasets. The cross-over procedure consisted of compiling the differences between independent measurements of ice thickness within a 50-m horizontal radius. We chose this since, for much of the ice sheet, it is close to the radius of the first Fresnel zone, which describes the circular area of a flat ice-base and that contributes to the leading edge of a radar echo. Accounting for the refractive index of ice $n$, the first Fresnel zone $R_{\mathrm{f}}$, is dependent on the radar 
Table 3. Digital elevation models used in compilation of the Bedmap2 surface grid.

\begin{tabular}{|c|c|c|}
\hline Source & Location (Fig. X) & Uncertainty estimate \\
\hline ASTER & Antarctic Peninsula & $\pm 26 \mathrm{~m}$, bias $+3 \mathrm{~m}$ (Cook et al., 2012) \\
\hline SPIRIT & Antarctic Peninsula & $\begin{array}{l}\text { Within } \pm 6 \mathrm{~m} \text { of ICESat elevations for } 90 \% \text { of } \\
\text { the data in areas of good contrast (Korona et al., 2009) }\end{array}$ \\
\hline $\begin{array}{l}\text { Satellite radar and laser altimetry } \\
\text { (Griggs and Bamber, 2011) }\end{array}$ & $\begin{array}{l}\text { Ice shelves away from } \\
\text { grounding zone }\end{array}$ & $\pm 15 \mathrm{~m}$, bias $5 \mathrm{~m}$ \\
\hline $\begin{array}{l}\text { Satellite radar and laser altimetry } \\
\text { (Bamber et al., 2009a) }\end{array}$ & $\begin{array}{l}\text { East and West Antarctic ice } \\
\text { sheet away from mountains }\end{array}$ & $\pm 23 \mathrm{~m}$, bias $<1 \mathrm{~m}$ \\
\hline $\begin{array}{l}\text { Satellite laser altimetry } \\
\text { (Brenner et al., 2007) }\end{array}$ & $\begin{array}{l}\text { Interior Antarctic Peninsula, some } \\
\text { mountain and coastal areas }\end{array}$ & $\begin{array}{l}\text { Estimate ranges from } \pm 0.4 \mathrm{~m} \text {, bias }-0.4 \mathrm{~m} \text { (relative to } \\
\text { airborne laser scanning) to } \pm 20 \mathrm{~m} \text {, bias }-24 \mathrm{~m} \text { (relative } \\
\text { to radar altimeter DEM over steeper slopes) }\end{array}$ \\
\hline OSU DEM (Liu et al., 1999) & Mountain areas & \pm 100 to $130 \mathrm{~m}$ \\
\hline
\end{tabular}

wavelength $\lambda$, terrain clearance $H$, and ice thickness $Z$, as

$R_{\mathrm{f}} \cong \sqrt{\frac{\lambda}{2}(H+n \times Z}$

After disqualifying nearby soundings from the same mission, we identified a total of 600973 crossover points. No account was taken of the direction of traverse or terrain clearance at the crossing points. The analysis produced a standard deviation of $\pm 51.2 \mathrm{~m}$, and the distribution of differences in ice thickness is shown in Fig. 10. It should be noted, however, that the cross-over values have a highly non-Gaussian distribution with a significant fraction many times greater than the standard deviation, hence, an unusually large number (94\%) of the cross-over values lie within one standard deviation of zero. The quoted standard deviation is, therefore, a pessimistic view of the vast majority of the crossovers, indeed, the median crossover difference is $-1 \mathrm{~m}$ and the interquartile range is $5 \mathrm{~m}$.

The spatial distribution of the majority of thickness crossover differences (Fig. 10) gives insight into their cause, which will include: differences introduced by roughness of the basal terrain, differences between radar instrumentation and differences in institutional processing methodology. The spatial spread of the relatively small number of large thickness-differences (1200 locations with a difference greater than $500 \mathrm{~m}$ ) provides a cautionary note for use of the gridded products. Some of these large differences appear to be due to the underlying topography whilst others appear to be caused by positional errors, and in particular from missions before the advent of GPS. The possibility that occasional erroneous data have been included in the compilation cannot be excluded.

\subsection{Other constraints on ice thickness}

Over the ice shelves, the published precision in thickness is variable, but is $\sim 100 \mathrm{~m}$, with biases of -13 to $+53 \mathrm{~m}$ (Griggs and Bamber, 2011). We have attempted to exclude areas most

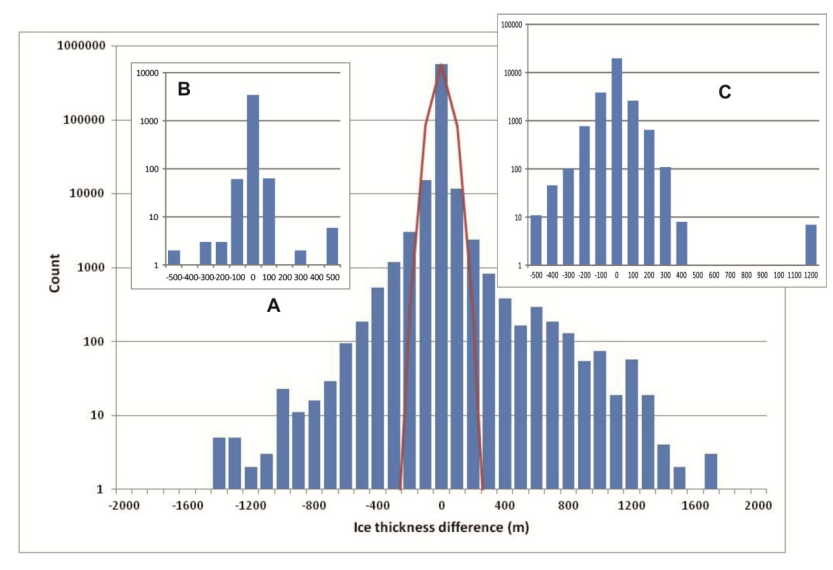

Fig. 10. Results of crossover analysis for direct ice-thickness measurements shown on a logarithmic scale. (A) represents the whole dataset, (B) areas with a smooth bed (test sample taken from the Siple coast) and (C) areas with a rough bed (test sample taken from the Gamburtsev Subglacial Mountains). Standard deviation is $51.2 \mathrm{~m}$ for the whole dataset, $33.37 \mathrm{~m}$ for smooth bedded areas and $74.59 \mathrm{~m}$ for areas with a rough bed. The Gaussian distribution with the same standard deviation is also shown, to demonstrate that there are more high-difference crossovers than would be expected for a normal distribution.

prone to bias and to correct others using radar data, but in some places the uncertainty is likely to remain at $\sim 150 \mathrm{~m}$.

While inversion of the gravity field can well represent the mean ice thickness over spatial scales of several tens to hundreds of kilometres, at the gridding resolution of Bedmap2 we find large deviations from these values associated with deep bed troughs. In the extreme case of the Recovery Glacier, we tested gravity-derived thickness with radar measurements not used in the gravity inversion. Over the deep Recovery trough, the gravity estimates were on average $1023 \mathrm{~m}$ too shallow $(n=35025, \mathrm{SD}=477 \mathrm{~m}$ ) while on neighbouring thin ice, they were $124 \mathrm{~m}$ too thick $(n=21222$, $\mathrm{SD}=407 \mathrm{~m}$ ). Over the extent of the radar survey (which was 
biased towards deeper ice), the gravity estimates were $437 \mathrm{~m}$ too shallow $(n=110024, \mathrm{SD}=600 \mathrm{~m})$. Given these findings, we estimate an uncertainty in ice thickness of $\pm 1000 \mathrm{~m}$ at any given point in the gravity-derived sections of the Bedmap2 grid.

\subsection{Synthetic data}

Thickness produced by the thin ice model is typically used in areas with relatively steep gradients of ice thickness and are constrained only at the zero-thickness isopleth. We estimate their uncertainties to be at least as large as those from interpolating radar measurements into unsampled areas over rough topography (discussed in following section), which are of order $\pm 300 \mathrm{~m}$. We estimate a similar uncertainty for our linear interpolation of glacier longitudinal profiles.

\subsection{Assessment of gridding and interpolation error}

Data distribution in airborne radar surveys is highly anisotropic: across-track sampling may be 3 or 4 orders of magnitude lower than sampling along flight tracks. Errors arise in the measurements themselves and in fitting and gridding of a surface using point data, but the largest Bedmap2 uncertainties will inevitably exist where we extrapolate through unsampled areas, i.e., the extrapolation error is additional to the measurement and gridding error. In Bedmap2, 34\% of cells have data within them and $80 \%$ have data within $20 \mathrm{~km}$, but the greatest distance from a grid cell to the nearest data point is $\sim 230 \mathrm{~km}$.

Here we assess the two error components associated with gridding:

1. the error arising from fitting a surface to point data and then gridding it;

2. the error that arises as the grid is interpolated into areas without measurements, for which a key question is: how does error increase with distance from the data?

We measure these two error components by splitting wellsampled surveys into two separate datasets. We grid one set (D1) and, (a) measure how well the surface fits the data at the D1 data points; and (b) use the rest of the dataset (D2) to see how well the grid did when extrapolated beyond the data in D1. Step 'a' is similar to the jack-knifing approach used in Bedmap1 (where random 10000 point samples were used, Lythe et al., 2001), but in step "b", we look at both the statistics of the error and the dependence of error on distance from data. This allows us to address the likely error in the majority of the Bedmap2 grid that is unsampled. We conducted this test in well-sampled areas over four characteristic subglacial landscape classes: "alpine", "low relief", "trough" and "mixed" (a region with a variety of landscape types). The alpine class was represented by the Gamburtsev Subglacial Mountains (Bell et al., 2011), the low relief class by the Siple Coast (Shabtaie and Bentley, 1987), the trough class by the
Carson Inlet (Vaughan et al., 2008), and the mixed landscape by an area in Wilkes land (Ferraccioli et al., 2009). Tables 4 and 5 show the results for each.

\subsubsection{Errors in fitting a gridded (Topogrid) surface to ice thickness data}

When we compared the gridded surfaces of thickness to the original data used in the gridding, we found median absolute errors ranging from $\sim 28$ to $140 \mathrm{~m}$ (Table 4, column 8), with the greatest average error in high-relief areas (Gamburtsev Subglacial Mountains). The examples from the Gamburtsev Subglacial Mountains and Carlson Inlet show greatest gridding errors where bed slopes are steepest, along trough flanks. This suggests that these errors arise from the simplification of a continuously and rapidly varying surface with mathematically defined curves, compounded by the representation of these curves with a regular, relatively low-resolution 5-km grid (i.e., generalisation and discretisation). In extreme cases, these thickness errors exceed $1000 \mathrm{~m}$. Where data are present in gridded cells, there is negligible bias in thickness (Table 5, columns 5 and 6). A conservative estimate of gridding error for the $34 \%$ of cells with measurements is, therefore, approximately $\pm 140 \mathrm{~m}$, but more typically $\pm 50 \mathrm{~m}$ (Table 4 and 5).

\subsubsection{Errors in extrapolation into unsampled areas}

These tests show that absolute error in extrapolated grids generally increases over a distance of up to $20 \mathrm{~km}$ from data (at a rate of $\sim 2$ to $8 \mathrm{~m} \mathrm{~km}^{-1}$ ) with the median error ranging from $\sim 100$ to $260 \mathrm{~m}$. Beyond $20 \mathrm{~km}$, error appears largely uncorrelated with distance and the median ranges from $\sim 130$ to $300 \mathrm{~m}$, with the largest errors occurring over high-relief landscapes. The maximum errors in these tests were $\sim 1800 \mathrm{~m}$ in cases where the extrapolation crossed deep, unsampled troughs.

In extrapolated areas, we have found biases of up to $\sim 80 \mathrm{~m}$ in these tests, but the biases may be either positive or negative. The larger biases are associated with a greater spread in the error data (Table 5). Figure 11 shows that the large bias $(-65 \mathrm{~m})$ results from extrapolation over an area of particularly high ground, i.e., it is dependent on bed topography. Given that the bias may be of either sign and depends on local topography, there does not appear to be bias inherent to the gridding and extrapolation technique. The implication is that if the sample size of signed extrapolation errors was increased over a varied landscape, the bias would tend to zero. Overall, these analyses suggest a conservative error estimate of $\pm 300 \mathrm{~m}$ for the $66 \%$ of cells without data in Bedmap2, a more typical estimate being $\pm 200 \mathrm{~m}$.

\subsection{Mapping uncertainty}

To map the distribution of the uncertainty described above, we defined three landscape classes (smooth, intermediate and 
Table 4. Summary of absolute error statistics. For Carlson Inlet, the full unsampled area is within $20 \mathrm{~km}$ of the gridding data.

\begin{tabular}{|c|c|c|c|c|c|c|c|c|c|}
\hline Region & $\begin{array}{r}\text { Extrapolation } \\
\text { error in first } 20 \mathrm{~km} \\
\text { of unsampled area } \\
(\text { median, } \mathrm{m})\end{array}$ & Count & $\operatorname{Max}$ & $\begin{array}{r}\text { Extrapolation } \\
\text { error in full } \\
\text { unsampled area } \\
(\text { median, m) }\end{array}$ & Count & $\operatorname{Max}$ & $\begin{array}{r}\text { Gridding error } \\
\text { in sampled } \\
\text { area } \\
\text { (median, m) }\end{array}$ & Count & Max \\
\hline $\begin{array}{l}\text { Gamburtsev } \\
\text { Mountains }\end{array}$ & 262 & 66684 & 1384 & 295 & 1048575 & 1732 & 142 & 1304572 & 1522 \\
\hline Siple Coast & 103 & 8719 & 1149 & 150 & 40170 & 1177 & 28 & 35214 & 1075 \\
\hline Carlson Inlet & - & - & - & 196 & 34818 & 1511 & 65 & 115002 & 1275 \\
\hline $\begin{array}{l}\text { Wilkes Land } \\
(100 \mathrm{~km})\end{array}$ & 101 & 207019 & 1478 & 131 & 536135 & 1817 & 37 & 536676 & 795 \\
\hline $\begin{array}{l}\text { Wilkes Land } \\
(300 \mathrm{~km})\end{array}$ & 108 & 100433 & 1228 & 221 & 825874 & 1876 & 39 & 246937 & 684 \\
\hline
\end{tabular}

Table 5. Summary of signed error statistics (bias).

\begin{tabular}{lrrrrrrr}
\hline Region & \multicolumn{2}{c}{$\begin{array}{c}\text { Signed extrapolation error } \\
\text { in unsampled areas }(\mathrm{m})\end{array}$} & & \multicolumn{2}{c}{$\begin{array}{c}\text { Signed gridding error } \\
\text { in sampled areas }(\mathrm{m})\end{array}$} \\
\cline { 2 - 3 } & Median & Mean & SD & & Median & Mean \\
\hline Gamburtsev Mtns & -65 & -74 & 422 & & -7 & -13 \\
Siple Coast & 10 & 18 & 246 & & 0 & -5 \\
Carlson Inlet & 78 & 93 & 437 & & -7 & -26 \\
Wilkes Land $(100 \mathrm{~km})$ & -6 & -1 & 300 & & 0 & -2 \\
Wilkes Land $(300 \mathrm{~km})$ & 49 & 54 & 399 & & -1 & -3 \\
\hline
\end{tabular}

rough) based on the standard deviation of the grid of ice thickness over $50 \mathrm{~km}$. The smooth class is typified by the thickness distribution on the Siple Coast, the rough is typified by the Gamburtsev Subglacial Mountains. Cells in each of these classes have an uncertainty depending on whether or not they contain thickness measurements. For cells with data, we do not calculate uncertainty based on the standard deviation or standard error of ice thickness within a cell because the within-cell sampling (number of samples and their distribution) is markedly inconsistent across the domain. For cells without data, our tests suggest that interpolation uncertainty has some dependency on distance from data over the first 5 to $20 \mathrm{~km}$ but this relationship is not well defined, hence, we assign a single, average value of uncertainty for all cells within a class that do not contain data. Additionally, we defined classes of gravity-derived thickness, altimetryderived ice shelf thickness and synthetic data. The Bedmap2 ice thickness uncertainty classes (Fig. 11) and their associated uncertainties (Fig. 12) are summarised in Table 6. The distribution of data and no-data cells is shown in Fig. 3.

\section{Discussion}

\subsection{New features}

The differences between Bedmap1, the most recently updated compilation (ALBMAP, Le Brocq et al., 2010), and
Bedmap2 are shown in Fig. 13. This visualisation shows that Bedmap2 contains substantial changes, with many areas being remapped by more than $\pm 500 \mathrm{~m}$. Changes are particularly noticeable in East Antarctica, where new data have been included in Bedmap2, but less noticeable in West Antarctica, where most crucial new data were already incorporated into ALBMAP, although, even here, in western Marie Byrd Land new data have made a significant difference to the bed.

So while Bedmap1 and ALBMAP provided an overview of Antarctic subglacial topography and several publications since then have described detailed vignettes of the regional bed (e.g., Holt et al., 2006; Vaughan et al., 2006; Ross et al., 2012), the combined improvements in data density and spatial coverage in Bedmap2 now show a landscape of mountain chains, networks of valleys, basins and deeply-carved troughs over most of the continent.

The inclusion of data from NASA's 2011 IceBridge Campaign from the Recovery Glacier, for example, reveals a basal trough that is one of the largest on the continent. A regionally low bed beneath this part of the ice sheet had previously been inferred from indirect analyses (Vaughan and Bamber, 1998; Le Brocq et al., 2008a), but it now appears that this glacier is underlain by a wide and deep trough stretching $650 \mathrm{~km}$ into the interior of East Antarctica. Apart from two sills, this trough is overdeepened over most of its length compared with its grounding line, a configuration that may have implications for stability of this part of the ice sheet. 
Table 6. Sources of uncertainty in Bedmap2 ice thickness uncertainty classes.

\begin{tabular}{lccc}
\hline $\begin{array}{l}\text { Uncertainty } \\
\text { class }\end{array}$ & $\begin{array}{c}\text { Cells with data } \\
\text { Gridding } \\
\text { uncertainty } \\
( \pm \mathrm{m})\end{array}$ & $\begin{array}{c}\text { Cells with data } \\
\text { Overall uncertainty } \\
\text { (measurement and } \\
\text { gridding, } \pm \mathrm{m})\end{array}$ & $\begin{array}{c}\text { Cells without } \\
\text { data Gridding } \\
\text { uncertainty } \\
( \pm \mathrm{m})\end{array}$ \\
\hline 1 (smooth) & 30 & 59 & 150 \\
2 (intermediate) & 65 & 83 & 200 \\
3 (rough) & 140 & 149 & 295 \\
4 (gravity-derived) & NA & 1000 & NA \\
5 (ice shelf) & NA & 150 & NA \\
6 (synthetic) & NA & NA & 300 \\
\hline
\end{tabular}

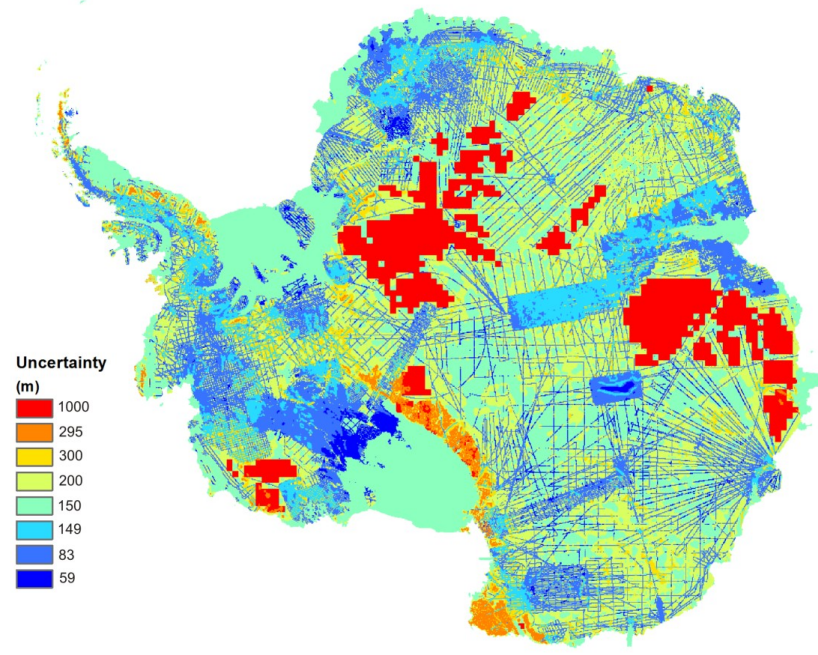

Fig. 11. Estimated uncertainty in ice thickness grid.

Mountain ranges such as the Transantarctic Mountains and Gamburtsev Subglacial Mountains, and major valleys such as the Lambert Rift and the valleys that form the West Antarctic Rift System (cf., Eagles et al., 2009; Bingham et al., 2012) can be seen both in detail and in the context of the continent as a whole. Particularly striking is the continuity of the steep flank of the Transantarctic Mountains for over $3000 \mathrm{~km}$ from Victoria Land, along the margin of the Ross Ice Shelf, and through the Whitmore Mountains and Ellsworth Subglacial Highlands, to the Ellsworth Mountains. Notable also is a possible continuation of the eastern Lambert Rift, which passes to the east of the Gamburtsev Subglacial Mountains (Ferraccioli et al., 2011) and south towards the Transantarctic Mountains.

A long, rather linear highland is now identifiable, running from close to the South Pole through East Antarctica roughly along on the $35^{\circ} \mathrm{E}$ meridian. Its southern portion, Recovery Subglacial Highlands, was previously identified and discussed in terms of its potential tectonic origin (Ferraccioli et al., 2011, though mistakenly named Resolution Subglacial Highlands in one figure), but its true scale is now clear;

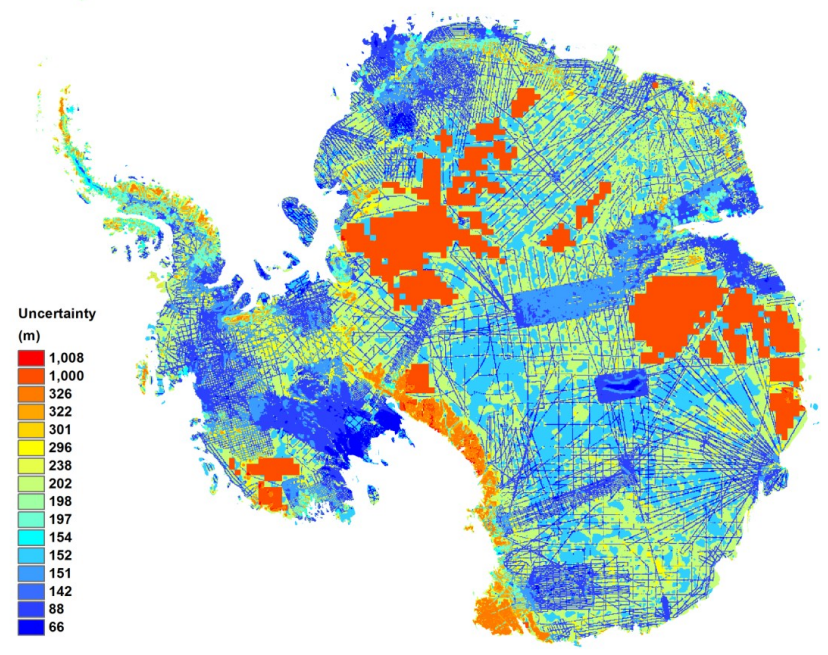

Fig. 12. Estimated uncertainty in bed elevation grid.

around $700 \mathrm{~km}$ in length, it is up to $3000 \mathrm{~m}$ higher than the surrounding bed.

Over the continental shelves, Bedmap2 has relied heavily on existing compilations of bathymetric data discussed elsewhere (e.g., Nitsche et al., 2007; Graham et al., 2009; Timmerman et al., 2010).

Beneath the grounded ice sheet, there remain two large areas where direct measurement of ice thickness, and consequently bed elevation, are absent: between Recovery and Support Force glaciers, and in Princess Elizabeth Land. Within these, the "poles of ignorance" are $\sim 230 \mathrm{~km}$ and $\sim 180 \mathrm{~km}$, respectively, from the nearest direct ice-thickness measurements. Although we map these using satellite gravity data, this technique is incapable of resolving shortwavelengths in the bed topography and these regions remain unrealistically smooth in the final ice-thickness and bed-elevation grids. While many areas would benefit from increased density of radar survey, even reconnaissance-level mapping of the bed in these regions would be invaluable. 
A, Bedmap2 to Bedmap1

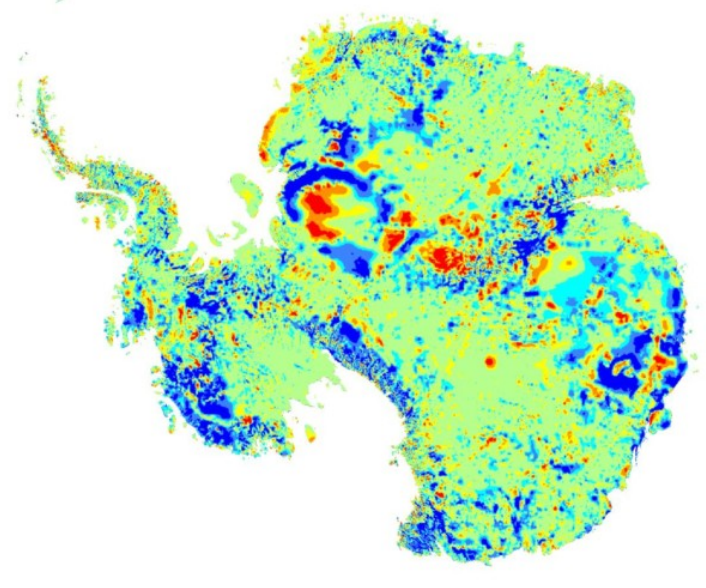

B, Bedmap2 to Albmap

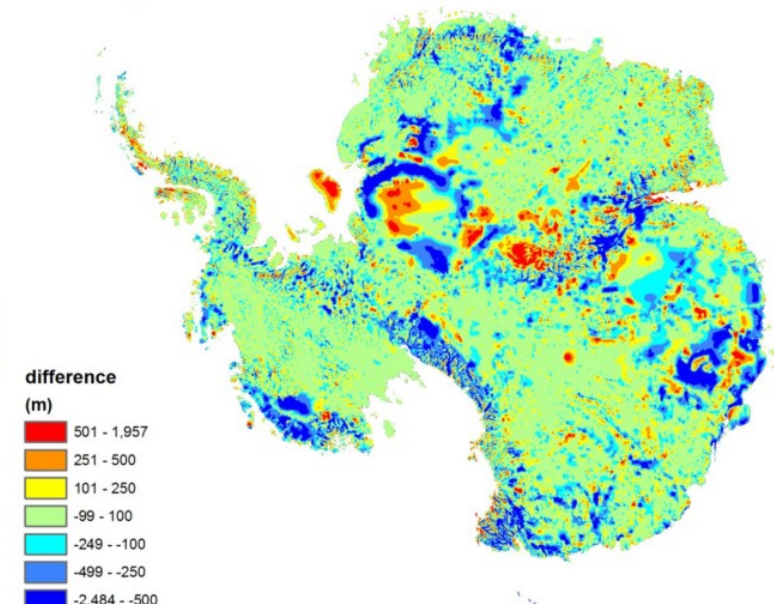

Fig. 13. Difference between bed grids: (A) shows difference between Bedmap2 and Bedmap1, and (B) shows the difference between Bedmap2 and the bed compilation of ALBMAP (Le Brocq et al., 2010). Red indicates areas where the Bedmap2 bed elevation is higher than previous grids.

\subsection{Statistics}

Table 7 provides an overview of the key statistics derived from Bedmap2 data compared to Bedmap1. Both these sets of statistics were calculated from $5-\mathrm{km}$ resolution grids. Correct area values are critical to all of these figures, so all datasets were re-projected to Lambert Equal area projection to ensure accurate representation of areas and volumes. This includes the data from the Bedmap1 compilation, which largely accounts for the difference to the original published values figures (Lythe et al., 2001).

Some of the main differences between Bedmap1 and Bedmap2 relate to the part of the ice sheet resting on a bed below present day sea-level. The area of ice sheet grounded below sea level is increased by $10 \%$. Similarly, the volume of ice sheet below sea level has increased by around $23 \%$, most of which is in East Antarctica. More than $73 \%$ of the total area of the Antarctic ice sheet resting on a bed grounded below sea-level is in East Antarctica.

For Bedmap2, the calculation of total ice mass was improved both by the improved description of the bed topography and the inclusion of a firn correction. We account for the volume of air contained within the firn in the nearsurface layers of the ice using modelled firn depth and density (Ligtenberg et al., 2011). We then calculated the mass of ice that could potentially contribute to sea-level rise. For parts of the ice sheet grounded on a bed above sea-level, this is simply the mass of ice lying between the ice-equivalent surface and the bed. For the part of the ice sheet grounded on a bed below sea-level, this is the mass of ice lying between the ice-equivalent surface and the flotation level calculated assuming ice density $917 \mathrm{~kg} \mathrm{~m}^{-3}$, sea-water density
$1030 \mathrm{~kg} \mathrm{~m}^{-3}$, and the GL04C geoid. Ice below the flotation level in the grounded ice sheet and in the ice shelves contributes to sea-level rise through its dilution effect on the ocean waters (Jenkins and Holland, 2007).

There is still substantial debate over the real potential for loss of ice in Antarctica to raise global sea level (e.g., Bamber et al., 2009b), and the second-order corrections required to evaluate the exact sea level change that would result from loss of ice in any particular area have been shown to be highly complex, involving as they do, crustal rebound, geoid modification (e.g., Spada et al., 2013), and thermosteric modification of the oceans (e.g., Shepherd et al., 2010). However, this simple sea-level rise potential is nonetheless important in indicating the relative importance of Antarctica to sealevel change, and the degree to which our understanding of the subglacial landscape of Antarctica is convergent. Using data largely collected during the 1970s (Drewry et al., 1982), Drewry et al. (1992), estimated the potential sea-level contribution of the Antarctic ice sheets to be in the range of 60$72 \mathrm{~m}$; for Bedmap1 this value was $57 \mathrm{~m}$ (Lythe et al., 2001), and for Bedmap2 it is $58 \mathrm{~m}$ (Table 8). Here, however, the agreement between Bedmap1 and Bedmap2 arises from two roughly counter-balancing differences; while the volume of ice has increased between Bedmap1 and Bedmap2, this has been offset by inclusion of a firn correction and a lowering of the mean bed depth which has reduced the total potential contribution.

In the data compiled for Bedmap1, the deepest bedelevation measurement by some margin was in the Bentley Subglacial Trench, where a data point of $-2496 \mathrm{~m}$ below sea level exists. Several recent campaigns have, however, identified deeper points in the subglacial bed. The 2008/09 
Table 7. Statistical comparison of Bedmap2 and the Bedmap1.

\begin{tabular}{lrr}
\hline & Bedmap1 & Bedmap2 \\
\hline Area including ice shelves $\left(10^{6} \mathrm{~km}^{2}\right)$ & 13.987 & 13.924 \\
Area excluding ice shelves $\left(10^{6} \mathrm{~km}^{2}\right)$ & 12.351 & 12.295 \\
Volume including ice shelves $\left(10^{6} \mathrm{~km}^{3}\right)$ & 26.07 & 26.92 \\
Volume excluding ice shelves $\left(10^{6} \mathrm{~km}^{3}\right)$ & 25.34 & 26.54 \\
Mean thickness including ice shelves (m) & 1859 & 1937 \\
Mean thickness excluding ice shelves (m) & 2034 & 2126 \\
Thickest ice Astrolabe Subglacial Basin $(\mathrm{m})$ & 4897 & 4897 \\
Mean bed depth (m) & 155.2 & 82.8 \\
Deepest bed point was Bentley Subglacial & -2496 & -2870 \\
Trough (m), now Byrd Glacier & & \\
Area below sea level (10 $\left.\mathrm{km}^{2}\right)$ & 5.01 & 5.50 \\
\% of total grounded area & 40.6 & 44.7 \\
Potential sea-level equivalent & $57 \mathrm{~m}$ & $58 \mathrm{~m}$ \\
\hline
\end{tabular}

AGAP campaign reported a bed depth of $\sim 2870 \mathrm{~m}$ below sea level near the grounding line of Byrd Glacier. Similarly, airborne radar data collected during recent CRESIS surveys 2011 indicated that the Byrd Glacier could be considerably deeper (P. Gogineni, personal communication, 2012). However, several other deep areas have also now been identified. For example, at the north end of Rutford Ice stream where the main mass of the ice stream turns sharply round the tip of the Ellsworth Mountains, the bed appears to reach more than $2.5 \mathrm{~km}$ below sea level. It is possible that a yet deeper subglacial bed exists either in one of these areas, or indeed, in an area yet to be identified. However, it can be said with confidence that the deepest surface of the continental crust on the planet lies somewhere beneath Antarctica.

\subsection{Caveats and cautions}

Care must be exercised when viewing the detail of the bed as in some places lack of measurements may result in misinterpretation. When analysing the detailed bed topography, refer to the data coverage. As noted previously, all gridding algorithms produce artefacts, and where these were obvious they have been manually removed or synthetic data have been added to the compilation to minimise their effect. Some examples still remain in the bed-elevation grid, such as in mountainous coastal areas where over-deepening may be introduced near sharp breaks in slope. Other characteristics of the gridding pattern include pock-marked surfaces where limited datasets have been over-interpreted by the gridding process, and areas where subtraction of the smooth surface of the gravity model from a more detailed surface DEM incorrectly give the bed the same textured appearance as the surface. In these particular cases, the artefacts have not been smoothed and are retained in the bed compilation.

While we have aimed to ensure that the gridded datasets are internally consistent and relatively smooth, the spatial derivative of the ice-thickness, surface-elevation and bedelevation products have not been smoothed. For this reason,
Table 8. Potential contribution to global sea level rise (m).

\begin{tabular}{lcccc}
\hline & Antarctica & WAIS & EAIS & APIS \\
\hline $\begin{array}{l}\text { Total potential } \\
\text { contribution }\end{array}$ & 58.3 & 4.3 & 53.3 & 0.2 \\
\hline $\begin{array}{l}\text { Potential from ice grounded } \\
\text { with a bed below sea-level }\end{array}$ & 3.4 & 19.2 & 0.1 \\
\hline
\end{tabular}

care should be taken when differentiating the grids to calculate, for example, glaciological driving stress, balance fluxes or sub-glacial hydrological pathways, where local elevation or thickness artefacts may become significant.

In compiling the large ice thickness dataset used here, we are aware that surveys are not uniformly successful in mapping ice thickness, and significant gaps still exist in data coverage. Along radio-echo flight lines, for example, the thickest areas of ice are often the least well sampled, presumably due to attenuation of the radar signal. Consequently, deep troughs with the thickest ice are prone to systematic underestimation of their thickness by an unknown amount.

\section{Conclusions}

The volume and distribution of ice in Antarctica are fundamental factors in determining the future behaviour of the ice sheets and their potential contribution to sea-level rise. Furthermore, the detailed form of the subglacial landscape and seafloor hold a record of the tectonic and geomorphic processes that created the Antarctic continent. Bedmap2 brings together the collective efforts of an international community of surveyors, since the beginning of the scientific era in Antarctica, to map the ice sheets and underlying landscape with an unprecedented combination of detail and extent.

Compared with the original Bedmap1 database, the Bedmap2 compilation includes 83 new ice-thickness surveys, satellite gravity data and a greatly revised and improved series of surface elevation, bathymetric, rock-outcrop, grounding line and ice-extent datasets. The number of ice thickness cells with data has doubled and $83 \%$ of the cells are now within $20 \mathrm{~km}$ of a thickness measurement. Relative to another recent assessment of ice thickness and topography (Le Brocq et al., 2010), we update ice thickness by more than $\pm 500 \mathrm{~m}$ over large parts of East Antarctica and in Marie Byrd Land, West Antarctica. This improved mapping in many areas now reveals the full scale of mountain ranges, valleys, basins and troughs, only fragments of which were previously indicated in local surveys.

Our data distribution grid highlights areas where data are still sparse or entirely absent, and we identify two poles of ignorance with no direct ice thickness measurements for several hundred kilometres. Our understanding of the 
Antarctic landscape would be greatly improved with even reconnaissance-level surveys in these areas.

In comparison to Bedmap1, the total volume of ice calculated from Bedmap2 has risen considerably (by $1.2 \times 10^{6} \mathrm{~km}^{3}$ or $4.6 \%$ ), but as the mean elevation of the bed has fallen significantly (by $72.6 \mathrm{~m}$ ), resulting in a much greater volume of ice below sea-level (from $2.1 \times 10^{6} \mathrm{~km}^{3}$ to $2.6 \times 10^{6} \mathrm{~km}^{3}$ ), the total potential contribution of Antarctic ice to sea-level rise has only risen modestly (from $57 \mathrm{~m}$ to $58 \mathrm{~m}$ ). However, the fact that more ice rests below sealevel means that on millennial timescales, increased volumes of ice are potentially vulnerable to ocean-driven loss. More analysis is required to quantify this risk, and the more immediate threat to coastal ice. The datasets of Bedmap2 provide a key resource in assessing these risks. The data products referred to here are available from: www.antarctica.ac. uk/bedmap2. This study should be cited as the source of these data products.

\section{Supplementary material related to this article is available online at: http://www.the-cryosphere.net/7/375/ 2013/tc-7-375-2013-supplement.pdf.}

Acknowledgements. The authorship of this publication reflects the institutes and individuals who have acquired data since the Bedmap1 compilation, however, many other scientists and support staff contributed to collecting and processing these data, and we are indebted to them all for their generosity in sharing their results. The many funding bodies, and specific grants that contributed to data acquisition are too numerous to be listed, but the compilation of Bedmap2 products was undertaken within the British Antarctic Survey's programme, Polar Science for Planet Earth.

Edited by: I. M. Howat

\section{References}

Bamber, J. L., Baldwin, D. J., and Gogineni, S. P.: A new bedrock and surface elevation dataset for modelling the Greenland ice sheet, Ann. Glaciol., 37, 351-356, 2003.

Bamber, J. L., Gomez-Dans, J. L., and Griggs, J. A.: A new 1 km digital elevation model of the Antarctic derived from combined satellite radar and laser data -Part 1: Data and methods, The Cryosphere, 3, 101-111, doi:10.5194/tc-3-101-2009, 2009a.

Bamber, J. L., Riva, R. E. M., Vermeersen, B. L. A., and LeBrocq, A. M.: Reassessment of the Potential Sea-Level Rise from a Collapse of the West Antarctic Ice Sheet, Science, 324, 901-903, doi:10.1126/science.1169335, 2009b.

Beaman, R.J., O’Brien, P. E., Post, A. L., and De Santis, L. : A new high-resolution bathymetry model for the Terre Adélie and George V continental margin, East Antarctica, Antarctic Sci., 23, 95-103, doi:10.1017/S095410201000074X, 2010.
Bell, R. E., Ferraccioli, F., Creyts, T. T., Braaten, D., Corr, H., Das, I., Damaske, D., Frearson, N., Jordan, T., Rose, K., Studinger, M., and Wolovick, M.: Widespread Persistent Thickening of the East Antarctic Ice Sheet by Freezing from the Base, Science, 331, 1592-1595, doi:10.1126/science.1200109, 2011.

Bentley, C. R.: The structure of Antarctica and its ice cover, in: Research in Geophysics Vol. 2, Solid Earth and Interface Phenomena, edited by: Odishaw, H., MIT Press, Cambridge, Mass., 335-389, 1964.

Bindschadler, R., Vornberger, P., Fleming, A., Fox, A., Mullins, J. L., Binnie, D., Paulsen, S. J., Granneman, B., and Gorodetzky, D.: The Landsat Image Mosaic of Antarctica, Remote Sens. Environ., 112, 4214-4226, 2008.

Bingham, R. G., Ferraccioli, F., King, E. C., Larter, R. D., Pritchard, H. D., Smith, A. M., and Vaughan, D. G.: Inland thinning of West Antarctic Ice Sheet steered along subglacial rifts, Nature, 487, 468-471, doi:10.1038/nature11292, 2012.

Bohlander, J. and Scambos, T.: Antarctic coastlines and grounding line derived from MODIS Mosaic of Antarctica (MOA), National Snow and Ice Data Center, Boulder, CO, USA, 2007.

Bolmer, S. T.: A note on the development of the bathymetry of the continental margin west of the Antarctic Peninsula from 658 to 718S and 658 to 788W. Deep-Sea Res. Pt. II, 55, 271-276, 2008

Brenner, A. C., DiMarzio, J. R., and Zwally, H. J.: Precision and accuracy of satellite radar and laser altimeter data over the continental ice sheets, IEEE Trans. Geosci. Remote Sensing, 45, 321331, doi:10.1109/TGRS.2006.887172, 2007.

Cook, A. J., Murray, T., Luckman, A., Vaughan, D. G., and Barrand, N. E.: A new 100-m Digital Elevation Model of the Antarctic Peninsula derived from ASTER Global DEM: methods and accuracy assessment, Earth Syst. Sci. Data, 4, 129-142, doi:10.5194/essd-4-129-2012, 2012.

DiMarzio, J., Brenner, A., Schutz, R., Shuman, C. A., and Zwally, H. J.: GLAS/ICESat $500 \mathrm{~m}$ laser altimetry digital elevation model of Antarctica: Digital media, National Snow and Ice Data Center, Boulder, CO, USA, 2007.

Drewry, D. J. and Jordan, S. R.: The bedrock surface of Antarctica, Scott Polar Research Institute, Cambridge, 1983.

Drewry, D. J., Jordan, S. R., and Jankowski, E.: Measured propoerties of the Antarctic Ice Sheet: Surface configuration, ice thickness, volume and bedrock characteristics, Ann. Glaciol., 3, 8391, 1982.

Drewry, D. J., Morris, E. M., Robin, G. D. Q., and Weller, G.: The Response of Large Ice Sheets to Climatic Change [and Discussion], Philos. T. Roy. Soc. B, 338, 235-242, doi:10.1098/rstb.1992.0143, 1992.

Eagles, G., Larter, R. D., Gohl, K., and Vaughan, A. P. M.: West Antarctic Rift System in the Antarctic Peninsula, Geophys. Res. Lett., 36, L21305, doi:10.1029/2009gl040721, 2009.

Ferraccioli, F., Armadillo, E., Jordan, T., Bozzo, E., and Corr, H.: Aeromagnetic exploration over the East Antarctic Ice Sheet: A new view of the Wilkes Subglacial Basin, Tectonophysics, 478, 62-77, doi:10.1016/j.tecto.2009.03.013, 2009.

Ferraccioli, F., Finn, C. A., Jordan, T. A., Bell, R. E., Anderson, L. M., and Damaske, D.: East Antarctic rifting triggers uplift of the Gamburtsev Mountains, Nature, 479, 388-392, doi:10.1038/nature10566, 2011.

Forste, C., Schmidt, R., Stubenvoll, R., Flechtner, F., Meyer, U., Konig, R., Neumayer, H., Biancale, R., Lemoine, J. M., Bru- 
insma, S., Loyer, S., Barthelmes, F., and Esselborn, S.: The GeoForschungsZentrum Potsdam/Groupe de Recherche de Geodesie Spatiale satellite-only and combined gravity field models: EIGEN-GL04S1 and EIGEN-GL04C, J. Geodesy, 82, 331-346, doi:10.1007/s00190-007-0183-8, 2008.

Graham, A. G. C., Fretwell, P. T., Larer, R. D., Hodgson, D. A., Wilson, C. K., Tate, A. J., and Morris, P.: New bathymetric compilation highlights extensive paleo-ice sheet drainage on the continental shelf South Georgia, sub-Antarctica, Geochem. Geophy. Geosy., 9, Q07011, doi:10.1029/2008GC001993, 2009.

Graham, A. G. C., Nitsche, F. O., and Larter, R. D.: An improved bathymetry compilation for the Bellingshausen Sea, Antarctica, to inform ice-sheet and ocean models, The Cryosphere, 5, 95106, doi:10.5194/tc-5-95-2011, 2011.

Griggs, J. A. and Bamber, J. L.: Antarctic ice-shelf thickness from satellite radar altimetry, J. Glaciol., 57, 485-498, 2011.

Haran, T., Bohlander, J., Scambos, T., Fahnestock, M., and compilers: MODIS mosaic of Antarctica (MOA) image map: Digital media, National Snow and Ice Data Center, Boulder, CO, USA, 2005.

Holt, J. W., Blankenship, D. D., Morse, D. L., Young, D. A., Peters, M. E., Kempf, S. D., Richter, T. G., Vaughan, D. G., and Corr, H. F. J.: New boundary conditions for the West Antarctic ice sheet: subglacial topography beneath Thwaites and Smith glaciers, Geophys. Res. Lett., 33, L09502, doi:10.1029/2005GL025561, 2006.

Hutchinson, M. F.: Calculation of hydrologically sound digital elevation models, Third International Symposium on Spatial Data Handling, Sydney, 1988.

Hutchinson, M. F.: A new procedure for gridding elevation and stream line data with automatic removal of spurious pits, J. Hydrol., 106, 211-232, 1989.

Jakobsson, M., Cherkis, N. Z., Woodward, J., MacNab, R., and Coakley, B.: New grid of Arctic bathymetry aids scientists and mapmakers, EOS Trans. AGU, 81, 89-96, 2000.

Jamieson, S. S. R., Hulton, N. R. J., Sugden, D. E., Payne, A. J., and Taylor, J.: Cenozoic landscape evolution of the Lambert basin, East Antarctica: the relative role of rivers and ice sheets, Glob. Planet. Change, 45, 35-49, 2005.

Jenkins, A. and Holland, D.: Melting of floating ice and sea level rise, Geophys. Res. Lett., 34, L16609, doi:10.1029/2007g1030784, 2007.

Kapitsa, A. P.: New data on ice thickness in the central regions of Antarctica, Soviet Antarctic Expedition Bulletin, Information Bulletin, 2, 247-250, 1964.

King, E. C., Hindmarsh, R. C. A., and Stokes, C. R.: Formation of mega-scale glacial lineations observed beneath a West Antarctic ice stream, Nat. Geosci., 2, 585-588, doi:10.1038/NGEO581, 2009.

Korona, J., Berthier, E., Bernard, M., Remy, F., and Thouvenot, E.: SPIRIT. SPOT 5 stereoscopic survey of Polar Ice: Reference Images and Topographies during the fourth International Polar Year (2007-2009), ISPRS-J. Photogramm., 64, 204-212, doi:10.1016/j.isprsjprs.2008.10.005, 2009.

Le Brocq, A. M., Hubbard, A., Bentley, M. J., and Bamber, J. L.: Subglacial topography inferred from ice surface terrain analysis reveals a large un-surveyed basin below sea level in East Antarctica, Geophys. Res. Lett., 35,L16503, doi:10.1029/2008g1034728, 2008a.
Le Brocq, A. M., Hubbard, A., Bentley, M. J., and Bamber, J. L.: Subglacial topography inferred from ice surface terrain analysis reveals a large un-surveyed basin below sea level in East Antarctica, Geophys. Res. Lett., 35, L16503, doi:10.1029/2008gl034728, 2008b.

Le Brocq, A. M., Payne, A. J., and Vieli, A.: An improved Antarctic dataset for high resolution numerical ice sheet models (ALBMAP v1), Earth Syst. Sci. Data, 2, 247-260, doi:10.5194/essd-2-247-2010, 2010.

Leuschen, C. and Allen, C.: IceBridge MCoRDS L2 Ice Thickness, 2009-2011: Digital media, NASA Distributed Active Archive Center at the National Snow and Ice Data Center, Boulder, CO, USA, 2012.

Ligtenberg, S. R. M., Helsen, M. M., and van den Broeke, M. R.: An improved semi-empirical model for the densification of Antarctic firn, The Cryosphere, 5, 809-819, doi:10.5194/tc-5-809-2011, 2011.

Liu, H. X., Jezek, K. C., and Li, B.: Development of Antarctic DEM by integrating cartographic and remotely sensed data: A GISbased approach., J. Geophys. Res., 104, 23199-23213, 1999.

Luyendyk, B. P., Wilson, D. S., and Siddoway, C.S.: Eastern margin of the Ross Sea rift in western Marie Byrd Land, Antarctica: Crustal structure and tectonic development, Geochem. Geophy. Geosy., 4, 1090, doi:10.1029/2002GC000462, 2003.

Lythe, M., Vaughan, D. G., and BEDMAP Consortium: BEDMAP - Bed topography of the Antarctic, BAS Misc., 9 Edn., SCAR/BAS, Cambridge, 2000.

Lythe, M., Vaughan, D. G., and The BEDMAP Consortium: BEDMAP: a new ice thickness and subglacial topographic model of Antarctica, J. Geophys. Res., 106, 11335-11352, 2001.

Morlighem, M., Rignot, E., Seroussi, H., Larour, E., Ben Dhia, H., and Aubry, D.: A mass conservation approach for mapping glacier ice thickness, Geophys. Res. Lett., 38, L19503, doi:10.1029/2011g1048659, 2011.

Nitsche, F. O., Jacobs, S., Larter, R., and Gohl, K.: Bathymetry of the Amundsen Sea continental shelf: implications for geology, oceanography, and glaciology, Geochem. Geophy. Geosy., 8, Q10009, doi:10.1029/2007GC001694, 2007.

Pritchard, H. D., Arthern, R. J., Vaughan, D. G., and Edwards, L. A.: Extensive dynamic thinning at the margins of the Greenland and Antarctic ice sheets, Nature, 461, 971-975, 2009.

Pritchard, H. D., Ligtenberg, S. R. M., Fricker, H. A., Vaughan, D. G., van den Broeke, M., and Padman, L.: Antarctic ice loss driven by ice-shelf melt, Nature, 484, 502-505, 2012.

Rebesco, M., Camerlenghi, A., Geletti, R., and Canals, M.: Margin architecture reveals the transition to the modern Antarctic ice sheet ca. 3 Ma., Geology, 34, 301-304, 2006.

Riedel, S., Jokat, W., and Steinhage, D.: Mapping tectonic provinces with airborne gravity and radar data in Dronning Maud Land, East Antarctica, Geophys. J. Int., 189, 414-427, doi:10.1111/j.1365-246X.2012.05363.x, 2012.

Rignot, E., Mouginot, J., and Scheuchl, B.: Antarctic grounding line mapping from differential satellite radar interferometry, Geophys. Res. Lett., 38, L10504, doi:10.1029/2011gl047109, 2011.

Roberts, J. L., Warner, R. C., Young, D., Wright, A., van Ommen, T. D., Blankenship, D. D., Siegert, M., Young, N. W., Tabacco, I. E., Forieri, A., Passerini, A., Zirizzotti, A., and Frezzotti, M.: Refined broad-scale sub-glacial morphology of Aurora Subglacial Basin, East Antarctica derived by an ice-dynamics-based inter- 
polation scheme, The Cryosphere, 5, 551—560, doi:10.5194/tc5-551-2011, 2011.

Ross, N., Bingham, R. G., Corr, H. F. J., Ferraccioli, F., Jordan, T. A., Le Brocq, A., Rippin, D. M., Young, D., Blankenship, D. D., and Siegert, M. J.: Steep reverse bed slope at the grounding line of the Weddell Sea sector in West Antarctica, Nat. Geosci., 5, 393-396, 2012.

Shabtaie, S. and Bentley, C. R.: West Antarctic Ice Streams draining into the Ross Ice Shelf: configuration and mass balance, J. Geophys. Res., 92, 1311-1336, 1987.

Shepherd, A., Wingham, D., Wallis, D., Giles, K., Laxon, S., and Sundal, A. V.: Recent loss of floating ice and the consequent sea level contribution, Geophys. Res. Let., 37, L13503, doi:10.1029/2010g1042496, 2010.

Smith, A. M., Murray, T., Nicholls, K. W., Makinson, K., Adalgeirsdottir, G., Behar, A. E., and Vaughan, D. G.: Rapid erosion, drumlin formation and changing hydrology beneath Antarctic ice stream, Geology, 35, 127-130, 2007.

Smith, W. H. F. and Sandwell, D. T.: Global sea floor topography from satellite altimetry and ship depth soundings, Science, 277, 1956-1962, doi:10.1126/science.277.5334.1956, 1997.

Snyder, J. P.: Map Projections: A Working Manual, USGS, 385 pp., 1987.

Spada, G., Bamber, J. L., and Hurkmans, R.: The gravitationally consistent sea-level fingerprint of future terrestrial ice loss, Geophys. Res. Lett., in press, doi:10.1029/2012GL053000, 2013.

Tapley, B. D., Bettadpur, S., Watkins, M., and Reigber, C.: The gravity recovery and climate experiment: Mission overview and early results, Geophys. Res. Lett., 31, L09607, doi:10.1029/2004g1019920, 2004.
Timmermann, R., Le Brocq, A., Deen, T., Domack, E., Dutrieux, P., Galton-Fenzi, B., Hellmer, H., Humbert, A., Jansen, D., Jenkins, A., Lambrecht, A., Makinson, K., Niederjasper, F., Nitsche, F., Nøst, O. A., Smedsrud, L. H., and Smith, W. H. F.: A consistent data set of Antarctic ice sheet topography, cavity geometry, and global bathymetry, Earth Syst. Sci. Data, 2, 261-273, doi:10.5194/essd-2-261-2010, 2010.

Vaughan, D. G. and Bamber, J. L.: Identifying areas of low-profile ice and outcrop damming in the Antarctic ice sheet by ERS-1 satellite altimetry, Ann. Glaciol., 27, 1-6, 1998.

Vaughan, D. G., Corr, H. F. J., Ferraccioli, F., Frearson, N., O’Hare, A., Mach, D., Holt, J. W., Blankenship, D. D., Morse, D., and Young, D. A.: New boundary conditions for the West Antarctic ice sheet: Subglacial topography beneath Pine Island Glacier, Geophys. Res. Lett., 33, L09501, doi:10.1029/2005GL025588, 2006.

Vaughan, D. G., Corr, H. F. J., Pritchard, H., Shepherd, A., and Smith, A. M.: Flow-switching and water-piracy between Rutford Ice Stream and Carlson Inlet, West Antarctica, J. Glaciol., 54, 41-48, 2008.

Vaughan, D. G., Barnes, D. K. A., Fretwell, P. T., and Bingham, R. G.: Potential open seaways across West Antarctica, Geochem. Geophy. Geosy., 12, Q10004, doi:10.1029/2011GC003688, 2011.

Welch, B. C. and Jacobel, R. W.: Analysis of deep-penetrating radar surveys of West Antarctica, US-ITASE 2001, Geophys. Res. Lett., 30, 1444 doi:10.1029/2003GL017210, 2003.

Wu, X. L. and Jezek, K. G.: Antarctic ice-sheet balance velocities from merged point and vector data, J. Glaciol., 50, 219-230, 2004. 